\title{
The Roles of Sex Hormones in the Course of Atopic Dermatitis
}

\author{
Naoko Kanda ${ }^{1, * \mathbb{D}}$, Toshihiko Hoashi ${ }^{2}$ and Hidehisa Saeki ${ }^{2}$ \\ 1 Department of Dermatology, Nippon Medical School, Chiba Hokusoh Hospital, Inzai, Chiba 270-1694, Japan \\ 2 Department of Dermatology, Nippon Medical School, Bunkyo-Ku, Tokyo 113-8602, Japan; \\ t-hoashi@nms.ac.jp (T.H.); h-saeki@nms.ac.jp (H.S.) \\ * Correspondence: n-kanda@nms.ac.jp; Tel.: +81-476-99-1111; Fax: +81-476-99-1909
}

Received: 16 July 2019; Accepted: 18 September 2019; Published: 20 September 2019

\begin{abstract}
Atopic dermatitis (AD) is a chronic inflammatory skin disease characterized by Thelper 2 cell (Th2)-shifted abnormal immunity, skin barrier impairment, and pruritus. The prevalence of AD in childhood is slightly higher in boys than in girls; after puberty, the sexual difference is reversed. The female preponderance in all generations exists in intrinsic AD with enhanced Th1 activity and nickel allergy, lacking increased serum IgE or filaggrin mutation. AD is often deteriorated before menstruation. We review the effects of sex hormones on immune responses and skin permeability barrier and propose possible hypotheses for the above phenomena. After puberty, the immune responses of patients are remarkably influenced by sex hormones. Estrogen and progesterone enhance the activities of Th2/regulatory T cell (Treg) but suppress Th1/Th17. Androgens suppress Th1/Th2/Th17 and induce Treg. The skin permeability barrier is fortified by estrogen but is impaired by progesterone and androgens. Dehydroepiandrosterone suppresses Th2 but enhances Th1. The amount of steroid sulfatase converting dehydroepiandrosterone sulfate to dehydroepiandrosterone is higher in women than in men, and thus, women might be more susceptible to the influence of dehydroepiandrosterone. The balance of modulatory effects of sex hormones on immune responses and skin barrier might regulate the course of $\mathrm{AD}$.
\end{abstract}

Keywords: atopic dermatitis; estrogen; progesterone; androgen; dehydroepiandrosterone; T helper 2 cell; skin barrier

\section{Introduction}

Atopic dermatitis (AD) is a chronic inflammatory skin disease characterized by Thelper 2 cell (Th2)-shifted abnormal immunity, skin barrier impairment, and pruritus (Figure 1) [1-3]. These three elements are mutually related and organize the clinicopathological features of AD. AD patients mostly show reduction of filaggrin expression partly due to mutation of this gene [1-3] and reveal decreases in water content and of ceramide synthesis in the stratum corneum (SC) [1-3]. Moreover, tight junctions (TJs) are dysfunctional in AD: the levels of zonula occludens 1 were decreased in the non-lesional sites of $\mathrm{AD}$, and the levels of zonula occludens 1 and claudin- 1 were decreased in the lesional sites relative to the levels in skin from healthy subjects [4]. Such impaired SC and TJ barriers allow the penetration of allergens like house dust mite, food, or pathogens, inducing sensitization to these allergens [1-3]. The AD lesional skin is infiltrated mainly by Th2 cells producing interleukin-4 (IL-4), IL-13, or IL-31 and by T22 cells producing IL-22, while chronic lesion is associated with the infiltration of Th1 cells producing interferon- $\gamma$ (IFN- $\gamma)$. Recently, the infiltration of Th17 cells is also noted in AD lesions [5]. Most AD patients show increased serum IgE levels and specific IgE antibodies against a variety of environmental allergens [1-3]. AD patients suffer from severe pruritus due to a variety of pruritogens like histamine, cytokines like thymic stromal lymphopoietin (TSLP), IL-31, IL-4, IL-13, or neuropeptides and abnormal 
extension of sensory nerves into the epidermis due to the increased expression of nerve growth factor or artemin or to the decreased expression of semaphorin 3A [2].

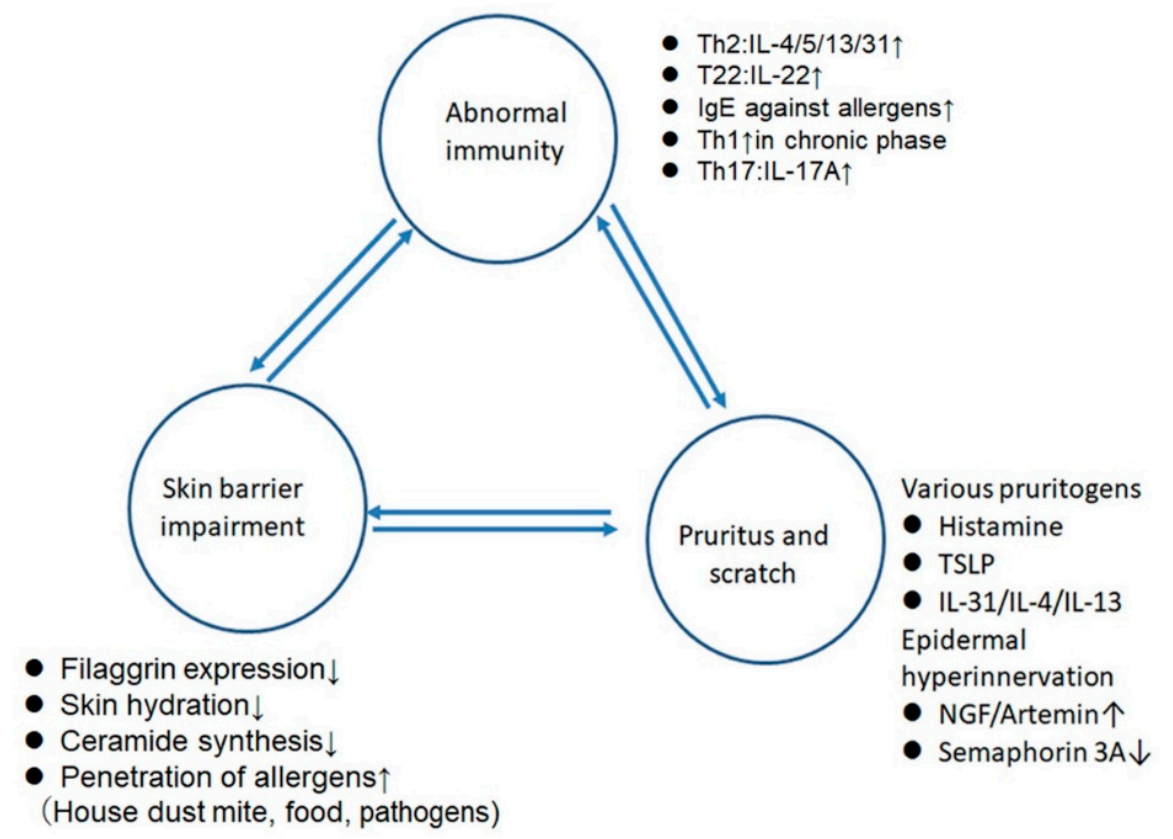

Figure 1. The three elements composing the pathogenesis of atopic dermatitis. Th2, T helper 2 cell; IL-4, interleukin-4; NGF, nerve growth factor; TSLP, thymic stromal lymphopoietin.

The prevalence of $\mathrm{AD}$ in childhood is slightly higher in boys than in girls: $8.7 \%$ and $5.6 \%$ for boys and girls, respectively, at $<4$ years old in the Netherlands [6]. After puberty, there is a slightly higher prevalence of $\mathrm{AD}$ in females: $5.7 \%$ and $8.1 \%$ for men and women, respectively, in Japan [7] or $6.04 \%$ and $8.01 \%$ in Europe and the USA [8]. This tendency is more remarkable in asthma, another Th2-shifted allergic disease [9]; the female:male percentage of patients was 35:65 at ages of 2 to 13 years, was inversed with 65:35 at ages of 23 to 64 years, are similar between those at ages of 14 to 22 years [10]. Adult female patients with asthma show more severe symptoms than adult male patients; the percentage of hospitalization for symptoms is $68 \%$ versus $32 \%$ in females versus males [11].

After puberty, the secretion of sex hormones from the ovary, testis, or adrenal gland is enormously increased. The immune responses or skin barrier in adolescents and adults might thus be more susceptible to influence by sex hormones compared to those in childhood. The effects of sex hormones might be related to the generation-dependent sexual difference in the prevalence of allergic diseases [12]. Interestingly, female preponderance of AD-like dermatitis possibly after puberty is detected in KFRS4/Kyo rats [13]. Dermatitis with severe pruritus initially appeared around 4 months of age, rapidly worsened from 6 to 8 months of age, and predominantly occurred in females: $100 \%$ of female versus $50 \%$ of male KFRS4/Kyo rats of 8 months old that were examined. The skin lesions were infiltrated with eosinophils, mast cells, and lymphocytes and were associated with increased plasma IgE levels and increased Th2 and Th17 cytokine mRNA levels in the skin-draining lymph nodes. Rats become sexually mature at about the sixth week but attain social maturity 5-6 months later [14], corresponding to the age with worsening dermatitis in KFRS4/Kyo rats. It is thus hypothesized that female sex hormones like estrogen or progesterone may contribute to the higher incidence of dermatitis in female KFRS4/Kyo rats.

On the other hand, female preponderance in all generations exists in intrinsic AD with enhanced Th1 activity and high incidence of nickel (Ni) allergy and without increased serum IgE values or filaggrin mutation [15]. Moreover, in female patients with AD, the disease is often deteriorated before menstruation, i.e., in the luteal phase when both estrogen and progesterone are secreted (Figure 2) [16]. 
These phenomena indicate that sex hormones might modulate the course of AD in the context of immune responses, skin barrier, or pruritus.

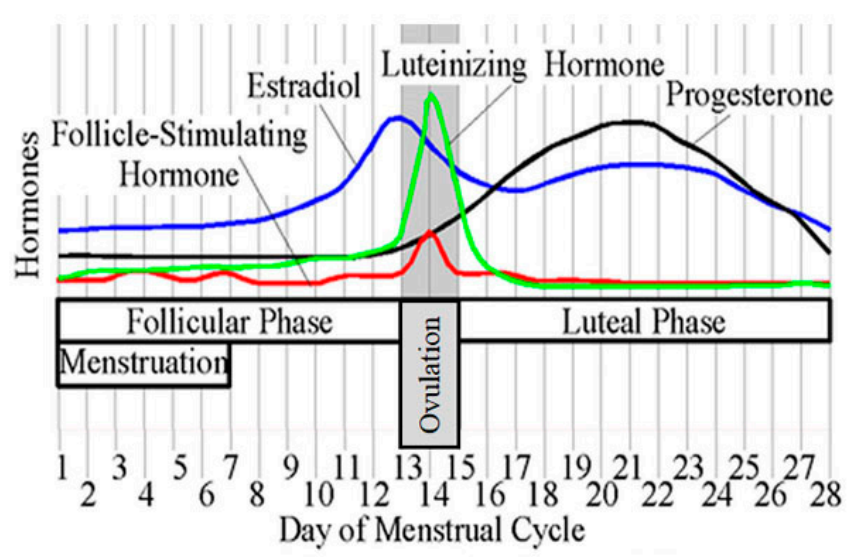

Figure 2. Menstrual cycle. Reprinted from https://commons.wikimedia.org/wiki/File:MenstrualCycle2. png. This file is licensed under the Creative Commons Attribution-Share Alike 3.0 Unported (https://creativecommons.org/licenses/by-sa/3.0/deed.en) license.

In this article, we firstly review the previous studies regarding the regulatory effects of sex hormones on the immune responses and skin barrier. We next propose hypotheses on possible hormonal regulation in the generation-dependent sexual difference in the prevalence of extrinsic $A D$, female preponderance of intrinsic $\mathrm{AD}$, and premenstrual deterioration of $\mathrm{AD}$.

\section{The Effects of Sex Hormones on Immune Responses}

\subsection{General Tendency (Table 1)}

Female hormones estrogen and progesterone mostly enhance the activities of Th2 cells and regulatory T cells (Tregs) but suppress Th1 and Th17 activities, which is favorable for the acceptance of allogeneic fetus during pregnancy [17]. Androgens like testosterone or dihydrotestosterone (DHT) are mostly immunosuppressive and suppress Th1, Th2, and Th17 activities but induce Treg activity. The magnitude of stimulation or suppression by female hormones is mostly higher than that by male hormones [18]. Generally in adolescents and adults, Th1 activities are higher in men than in women while Th2 activities are much higher in women than in men [18]. The sexual differences in Th17 or Treg activities are ambiguous. Dehydroepiandrosterone (DHEA) produced in the adrenal cortex enhances Th1 responses and shifts the balance of Th1/Th2 toward Th1-dominant immunity [19]. Females have higher amounts of steroid sulfatase converting dehydroepiandrosterone sulfate (DHEAS) to active DHEA and, thus, might be more susceptible to influence by DHEA compared to males [20]. To date, it has not been precisely examined how sex hormones regulate the activity of Th22 cells producing IL-22 alone without IL-17A.

Table 1. The effects of sex hormones on immune responses and skin barrier impairment.

\begin{tabular}{cccccc}
\hline Hormones & Th1 & Th2 & Th17 & Treg & $\begin{array}{c}\text { Skin Barrier } \\
\text { Impairment }\end{array}$ \\
\hline Androgen & $\downarrow$ & $\downarrow$ & $\downarrow$ & $\uparrow$ & $\uparrow$ \\
Estrogen & $\uparrow \sim \downarrow$ & $\uparrow$ & $\uparrow \sim \downarrow$ & $\uparrow$ & $\downarrow$ \\
Progesterone & $\downarrow$ & $\uparrow$ & $\downarrow$ & $\uparrow$ & $\uparrow$ \\
DHEA & $\uparrow$ & $\downarrow$ & $?$ & $?$ & $?$ \\
\hline Total activity & $\mathrm{F}<\mathrm{M}$ & $\mathrm{F} \gg \mathrm{M}$ & $?$ & $?$ & $\mathrm{~F}<\mathrm{M}$ \\
\hline
\end{tabular}

$\uparrow$, Moderate stimulation; $\mathbf{\uparrow}$, strong stimulation; $\downarrow$, moderate suppression; $\downarrow$, strong suppression; ?, ambiguous; $\uparrow \sim \downarrow$, Stimulatory or inhibitory effects dependent on the concentration, tissue, or disease context; Th1, T helper 1 cell; Treg, regulatory T cell; DHEA, dehydroepiandrosterone; F, female; $\mathrm{M}$, male. 


\subsection{Female Hormones}

\subsubsection{Estrogens (Table 2)}

Table 2. Summary of the effects of estrogen on the activities of T helper 1 cell (Th1), Th2, Th17, and regulatory $\mathrm{T}$ cell (Treg).

\begin{tabular}{|c|c|c|c|c|}
\hline Effects & $\begin{array}{l}\text { Vivo/ } \\
\text { Vitro }\end{array}$ & Species & Th Activities & References \\
\hline \multicolumn{5}{|c|}{ Adaptive Immunity } \\
\hline T-bet $\uparrow$ & vivo & mice & Th1 $\uparrow$ & {$[21]^{*}$} \\
\hline IFN- $\gamma \uparrow$ & vivo & mice & Th1个 & {$[21]^{*}$} \\
\hline 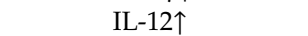 & vivo & mice & Th1个 & {$[21]^{*}$} \\
\hline T-bet $\downarrow$ & vitro & human & Th1 $\downarrow$ & {$[22]^{* *}$} \\
\hline T-bet $\downarrow$ & vivo & mice & Th1 $\downarrow$ & {$[23]^{\dagger}$} \\
\hline IFN- $\gamma \downarrow$ & vivo & mice & Th1 $\downarrow$ & {$[24]^{+}$} \\
\hline IFN- $\gamma \downarrow$ & vitro & mice & Th1 $\downarrow$ & {$[25]^{\S}$} \\
\hline IFN- $\gamma \downarrow$ & vitro & human & Th1 $\downarrow$ & {$[22]^{* *}$} \\
\hline IFN- $\gamma \downarrow$ & vivo & mice & Th1 $\downarrow$ & {$[23]^{+}$} \\
\hline GATA-3个 & vivo & mice & Th $2 \uparrow$ & {$[26]$} \\
\hline GATA-3^ & vivo & mice & $\operatorname{Th} 2 \uparrow$ & {$[23]^{+}$} \\
\hline $\mathrm{IL}-4 \uparrow$ & vivo & mice & Th2 $2 \uparrow$ & {$[26]$} \\
\hline $\mathrm{IL}-4 \uparrow$ & vivo & mice & Th $2 \uparrow$ & {$[23]^{+}$} \\
\hline $\begin{array}{c}\text { B cells } \\
\text { IgM, IgE } \uparrow\end{array}$ & vitro & mice & Th2 $2 \uparrow$ & [27] \\
\hline RORc $\downarrow$ & vivo & mice & Th17 & {$[24]^{+}$} \\
\hline RORc $\downarrow$ & vitro & human & Th17〕 & [28] \\
\hline RORc $\downarrow$ & vitro/vivo & mice & 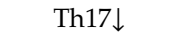 & [25] \\
\hline $\operatorname{ROR} \gamma \mathrm{t} \downarrow$ & vitro & human & 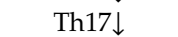 & {$[22]^{* *}$} \\
\hline $\mathrm{ROR} \gamma \mathrm{t} \downarrow$ & vivo & mice & 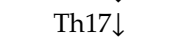 & {$[23]^{+}$} \\
\hline IL-17A $\downarrow$ & vitro & mice & 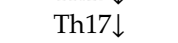 & {$[25]^{\S}$} \\
\hline IL-17A $\downarrow$ & vivo & mice & Th17 $\downarrow$ & {$[24]^{+}$} \\
\hline IL-17A $\downarrow$ & vitro & human & Th17』 & {$[22]^{* *}$} \\
\hline IL-17A $\downarrow$ & vivo & mice & 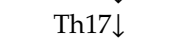 & {$[23]^{+}$} \\
\hline 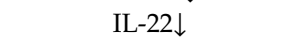 & vitro & mice & Th17 $\downarrow$ & {$[25]^{\S}$} \\
\hline IL-17A $\uparrow$ & vivo & mice & Th17^ & {$[29] \ddagger$} \\
\hline $\mathrm{IL}-21 \uparrow$ & vivo & mice & Th17个 & {$[29] \ddagger$} \\
\hline $\mathrm{IL}-22 \uparrow$ & vivo & mice & Th17^ & {$[21]^{*}$} \\
\hline $\operatorname{ROR} \gamma t \uparrow$ & vivo & mice & Th17^ & {$[21]^{*}$} \\
\hline $\mathrm{ROR} \gamma \mathrm{t} \uparrow$ & vivo & mice & Th17个 & {$[29] \ddagger$} \\
\hline Foxp3个 & vitro & human & Treg $\uparrow$ & {$[28]$} \\
\hline Foxp3个 & vitro & human & Treg $\uparrow$ & [30] \\
\hline Foxp3个 & vivo & mice & Treg $\uparrow$ & {$[23]^{\dagger}$} \\
\hline Foxp3个 & vivo/vitro & mice & Treg $\uparrow$ & [31] \\
\hline IL-10个 & vivo & mice & Treg $\uparrow$ & {$[23]^{+}$} \\
\hline IL10个 & vitro & mice & Treg $\uparrow$ & [12] \\
\hline TGF- $\uparrow$ & vivo & mice & Treg $\uparrow$ & {$[23]^{+}$} \\
\hline Foxp $3 \downarrow$ & vitro & human & Treg $\downarrow$ & {$[22]^{* *}$} \\
\hline 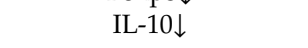 & vitro & human & Treg $\downarrow$ & {$[22]^{* *}$} \\
\hline \multicolumn{5}{|c|}{ Innate immunity } \\
\hline 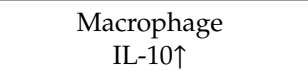 & vitro & human & Th2 $2 \uparrow$ & [32] \\
\hline $\begin{array}{c}\text { Macrophage } \\
\text { IL-1RA } \uparrow\end{array}$ & vitro & human & Th2 $\uparrow$ & [32] \\
\hline $\begin{array}{l}\text { Macrophage } \\
\text { CD192 }\end{array}$ & vitro & human & Th2 $2 \uparrow$ & [32] \\
\hline Mast cell degranulation $\uparrow$ & vitro & mice & Th2 $2 \uparrow$ & [33] \\
\hline
\end{tabular}

$\uparrow$, stimulation; $\downarrow$, suppression; ROR, retinoic acid receptor-related orphan nuclear receptor; Foxp3, forkhead box P3; GATA3, GATA binding protein 3; T-bet, T-box-containing protein expressed in T cells; STAT3, signal transducer and activator of transcription 3; *, Estrous level of estradiol (E2) induced the effects, pregnancy-level of E2 did not; **, Effects of polyphenolic compound delphinidin; †, Pregnancy-levels of E2; $\ddagger$, Estrogen receptor agonist diarylpropionitrile; $\S, 10^{-10} \mathrm{M}$ E2 induced the effects, but $10^{-11} \mathrm{E} 2$ did not; Effects of selective estrogen receptor modulator.

Estrogens are estrone, estradiol (E2), and estriol. E2 is produced by ovarian granulosa cells and placenta. The immunomodulatory effects of E2 are mediated mainly by intracellular estrogen receptor 
$\alpha(E R \alpha)$ and $E R \beta$ or structurally unrelated membrane G-protein-coupled estrogen receptor 1. E2 promotes Th2 activity [26,32]: E2 at pregnancy levels of concentration enhanced the expression of GATA binding protein 3 (GATA3) and IL-4 in ovariectomized experimental autoimmune encephalomyelitis (EAE) model mice [23]. E2 also enhanced IgE production in mouse splenocytes [27].

The effects of E2 on Th1 cells are complex and depend on the concentration, tissue, or disease context: E2 at estrous levels of concentration in vivo enhanced the expression of T-box-containing protein expressed in T cell (T-bet) and IFN- $\gamma$ production in female ovariectomized autoimmune thyroiditis model mice [21]. In contrast, E2 at pregnancy levels of concentration reduced the production of IL-12 and IFN- $\gamma$ in phytohemagglutinin plus lipopolysaccharide (LPS)-stimulated human whole blood cells [34]. The high-dose estrogen treatment reduced the expression of IFN- $\gamma$ and T-bet in EAE model mice [23]. It appears that pregnancy levels of $\mathrm{E} 2$ shift the Th1/Th2 balance towards Th2 profiles, inhibiting Th1 development [22,35].

Though E2 mostly suppresses Th17 activity [22,24], several studies reported the stimulatory effects of E2 on Th17 cells: E2 at estrous levels of concentration enhanced the expression of IL-21 and retinoic acid receptor-related orphan nuclear receptor $\gamma \mathrm{t}(\mathrm{ROR} \gamma \mathrm{t})$ in female ovariectomized autoimmune thyroiditis model mice [21]. Diarylpropionitrile, a specific agonist of ER $\beta$ and not of ER $\alpha$, in vivo enhanced IL-17A, IL-21, and ROR $\gamma \mathrm{t}$ mRNA levels in splenocytes of experimental autoimmune thyroiditis model mice through binding of the agonist-activated ER $\beta$ to IL-17A and IL-21 gene promoters [29]. In contrast, E2 at estrous levels of concentration suppressed RORc expression and IL-17A and IL-22 production in response to sperm or Candida albicans in female ovariectomized mice [25]. The treatment with estrogen at pregnancy levels of concentration suppressed ROR $\gamma \mathrm{t}$ expression and IL-17A and IL-6 production in EAE model mice [23]. E2 upregulated the expression of repressor of estrogen receptor activity (REA) and recruited REA to the estrogen response elements (EREs) on the ROR $\gamma t$ promoter region, thus inhibiting ROR $\gamma t$ expression [36].

E2 enhances the activity and/or proliferation of Tregs [28]: E2 enhanced the expression of forkhead box P3 (Foxp3) by inducing binding of the E2/ER $\alpha$ complex to EREs on a human Foxp3 promoter [30]. Polanczyk et al. reported that E2 in vivo and in vitro increased Foxp3 expression and Treg number in mice [31]. Tai et al. reported that E2, at physiological doses, in vitro stimulated the conversion of CD4+CD25-T cells into CD4+CD25+T cells, which exhibited the enhanced expression of Foxp3 and IL-10 in mice [12].

Estrogen also acts on mast cells and induces IgE-mediated degranulation [33,37], indicating the stimulatory effects of E2 on allergic diseases. In Th2 hapten toluene diisocyanate (TDI)-sensitized allergic airway inflammation model mice, ER $\alpha$ and ER $\beta$ agonists induced IL-33 production of airway epithelial cells and eosinophil infiltration into the lung [38].

\subsubsection{Progesterone (Table 3)}

Progesterone is secreted by the ovarian corpus luteum and placenta and plays a major role in the establishment and maintenance of pregnancy. The effects of progesterone are mainly mediated by intracellular progesterone receptors while some rapid non-transcriptional actions are mediated by structurally unrelated membrane progesterone receptors [17]. 
Table 3. Summary of the effects of progesterone on the activities of T helper 1 cell (Th1), Th2, Th17, and regulatory $\mathrm{T}$ cell (Treg).

\begin{tabular}{|c|c|c|c|c|}
\hline Effects & Vivo/Vitro & Species & Th Activities & References \\
\hline \multicolumn{5}{|c|}{ Adaptive Immunity } \\
\hline T-bet $\downarrow$ & vitro & cows & Th1 $1 \downarrow$ & [39] \\
\hline IFN- $\gamma \downarrow$ & vitro & cows & Th1 $\downarrow$ & [39] \\
\hline PIBF- STAT6 $\uparrow$ & vitro & human & Th2 $\uparrow$ & [40] \\
\hline GATA3 $\uparrow$ & vivo/vitro & mice & Th2 $2 \uparrow$ & [41] \\
\hline $\mathrm{IL}-4 \uparrow$ & ex vivo & mice & Th $2 \uparrow$ & [42] \\
\hline $\mathrm{IL}-4 \uparrow$ & vitro & cows & Th2 $2 \uparrow$ & [39] \\
\hline $\mathrm{IL}-4 \uparrow$ & vivo & mice & Th2 $2 \uparrow$ & [42] \\
\hline $\begin{array}{l}\text { B cell } \\
\text { IgE } \uparrow\end{array}$ & vivo & mice & $\operatorname{Th} 2 \uparrow$ & [42] \\
\hline $\begin{array}{c}\text { Vaginal epithelial cell } \\
\text { TSLP } \uparrow\end{array}$ & vivo/vitro & mice & $\operatorname{Th} 2 \uparrow$ & [41] \\
\hline $\begin{array}{l}\text { STAT3 RORC CCR6 IL-23R } \\
\text { IL-6R AHR } \downarrow\end{array}$ & vitro & human & Th17 $\downarrow$ & [43] \\
\hline $\operatorname{ROR} \gamma \mathrm{t} \downarrow$ & $\begin{array}{l}\text { vivo/ } \\
\text { vitro }\end{array}$ & mice & Th17 $\downarrow$ & [41] \\
\hline RORC $\downarrow$ & vitro & cows & 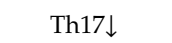 & [39] \\
\hline IL-17A $\downarrow$ & vitro & human & Th17 $\downarrow$ & [43] \\
\hline IL-17A $\downarrow$ & vitro & cows & Th17 $\downarrow$ & [39] \\
\hline IL-17F $\downarrow$ & vitro & human & Th17〕 & [43] \\
\hline 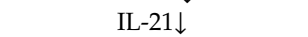 & vitro & human & Th17」 & [43] \\
\hline CD39+ & vivo & mice & Th17个* & [44] \\
\hline IL-17A $\uparrow$ & vivo & mice & Th17个※ & [44] \\
\hline $\mathrm{IL}-22 \uparrow$ & vivo & mice & Th17个* & [44] \\
\hline IL-23个 & vivo & mice & Th17个* & [44] \\
\hline $\mathrm{IL}-6 \uparrow$ & vivo & mice & Th17个* & [44] \\
\hline TGF- $\beta \uparrow$ & vivo & mice & Th17^* & [44] \\
\hline Foxp $3 \uparrow$ & vitro & mice & Treg $\uparrow$ & [43] \\
\hline Foxp $3 \uparrow$ & vivo/vitro & mice & Treg $\uparrow$ & [41] \\
\hline \multicolumn{5}{|c|}{ Innate Immunity } \\
\hline $\begin{array}{l}\text { Airway epithelial cells } \\
\text { Amphiregulin } \uparrow\end{array}$ & vivo & mice & & [44] \\
\hline
\end{tabular}

※,CD39+ regulatory Th17 cells; $\uparrow$, stimulation; $\downarrow$, suppression; ROR, retinoic acid receptor-related orphan nuclear receptor; Foxp3, forkhead box P3; GATA3, GATA binding protein 3; T-bet, T-box-containing protein expressed in T cells; STAT, signal transducer and activator of transcription; AHR, aryl hydrocarbon receptor; CCR6 CC-type chemokine receptor 6; TSLP, thymic stromal lymphopoietin; PIBF, progesterone-induced blocking factor.

Progesterone promotes Th2 activity [45]: progesterone acts on T cells and induces the secretion of progesterone-inducible blocking factor (PIBF) which binds IL-4 receptor $\alpha(\mathrm{IL}-4 \mathrm{R} \alpha) / \mathrm{PIBFR}$ on the cell surface and induces the Janus kinase 1 (Jak1)/signal transducer and activator of transcription 6 (STAT6) pathway to increase the production of Th2 cytokines like IL-4 or IL-10 [40]. Progesterone increased TSLP expression in vaginal epithelium and GATA-3 expression and IL-4 production in CD4+T cells in Neisseria gonorhoeae-infected vagina of mice [41]. Progesterone treatment increased IL-4 production in peripheral blood mononuclear cells (PBMCs) from pregnant cows [39]. The pro-Th2 effect of progesterone is consistent with the higher IL-4 and IL-10 production in PBMCs from pregnant cows with high progesterone levels than those from nonpregnant cows [39]. Progesterone treatment on ovariectomized asthma model mice increased serum IgE levels and IL-4 production in bronchoalveolar lavage cells [42], indicating the contribution of progesterone to the elicitation of allergic diseases.

In contrast, progesterone directly suppresses Th1 development in mice [46]. Progesterone treatment suppressed T-bet expression and IFN- $\gamma$ production in PBMCs from pregnant cows [39]. The Th1-suppressive effect of progesterone is also consistent with the decreased IFN- $\gamma$ production in PBMCs from pregnant cows compared to those from nonpregnant cows [39].

Progesterone suppresses the differentiation of Th17 cells: progesterone in vitro suppressed IL-17A, IL-17F, and IL-21 production and RORc expression in human cord blood cells under the Th17-differentiation conditions and also suppressed their STAT3 phosphorylation in response to IL-6 [43]. Progesterone suppressed ROR $\gamma t$ expression and decreased IL-17A-producing CD4+T cell numbers in Neisseria gonorhoeae-infected vagina of mice [41]. 
Progesterone induces the differentiation of Tregs [44]: progesterone in vitro drove the allogeneic activation-induced differentiation of human cord blood naive T cells into immunosuppressive Tregs, which highly expressed FoxP3 and memory T cell marker CD45RO [43]. Progesterone increased the percentage of CD4+CD25+Foxp3+ Tregs in Neisseria gonorhoeae-infected vagina of mice [41]. These reports totally suggest that progesterone favors Th2/Treg activities but suppresses Th1/Th17 activities, which might be favorable for tolerance to allogeneic fetus and for maintenance of pregnancy [17].

\subsection{Androgens (Table 4)}

Table 4. Summary of the effects of androgens on the activities of T helper 1 cell (Th1), Th2, Th17, and regulatory $\mathrm{T}$ cell (Treg).

\begin{tabular}{|c|c|c|c|c|}
\hline Effects & Vivo/Vitro & Species & Th Activities & References \\
\hline \multicolumn{5}{|c|}{ Adaptive Immunity } \\
\hline ptpn1个STAT4 $\downarrow$ & vivo/ vitro & human and mice & Th1 $\downarrow$ & [47] \\
\hline PPAR $\alpha \uparrow$ & vitro/vivo & mice & Th1 $\downarrow$ & [48] \\
\hline IFN- $\gamma \downarrow$ & vitro/vivo & mice & Th1 $\downarrow$ & [48] \\
\hline IFN- $\gamma \downarrow$ & vitro & mice & Th1 $\downarrow$ & [49] \\
\hline IFN- $\gamma \downarrow$ & vitro & human & Th1 $\downarrow$ & [50] \\
\hline $\mathrm{IL}-12 \downarrow$ & vitro & human & Th1 $\downarrow$ & [50] \\
\hline CXCL10 & vitro & human & Th1 $\downarrow$ & [50] \\
\hline 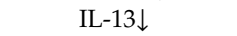 & vitro & human & Th2 $2 \downarrow$ & [50] \\
\hline 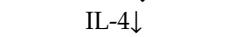 & vitro & human & Th2 $2 \downarrow$ & [50] \\
\hline 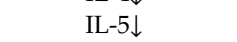 & vitro & human & Th2 $\downarrow$ & [50] \\
\hline $\begin{array}{l}\text { B cell number } \downarrow \\
\text { B cell }\end{array}$ & vivo & mice & Th2 $2 \downarrow$ & [51] \\
\hline $\begin{array}{l}\text { Antigen-specific } \operatorname{IgE} \\
\text { production } \downarrow\end{array}$ & vivo & mice & Th2 $2 \downarrow$ & [52] \\
\hline PPAR $\gamma \downarrow$ & vitro/vivo & mice & Th17个 & [48] \\
\hline IL-17A $\uparrow$ & vitro/vivo & mice & Th17个 & [48] \\
\hline IL-23R $\downarrow$ & vivo & mice & 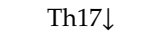 & [53] \\
\hline IL-23R $\downarrow$ & vitro & Mice & Th17」 & [54] \\
\hline IL-17A $\downarrow$ & vitro & mice & Th17〕 & [49] \\
\hline IL-17A $\downarrow$ & vivo & mice & 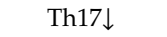 & [53] \\
\hline IL-17A $\downarrow$ & vitro & human & Th17〕 & [50] \\
\hline ARE-Foxp $3 \uparrow$ & vitro & human & Treg $\uparrow$ & [55] \\
\hline IL-10个 & vitro & human & Treg $\uparrow$ & [50] \\
\hline \multicolumn{5}{|c|}{ Innate Immunity } \\
\hline 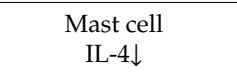 & vivo & mice & Th2 $2 \downarrow$ & [53] \\
\hline $\begin{array}{c}\text { ILC2 } \\
\text { IL-13】 }\end{array}$ & vivo & mice & Th2 $\downarrow \downarrow$ & [53] \\
\hline $\begin{array}{l}\text { Basophil } \\
\text { IL-4 } \downarrow\end{array}$ & vivo & mice & Th2 $\downarrow$ & [53] \\
\hline
\end{tabular}

$\uparrow$, stimulation; $\downarrow$, suppression; ROR, retinoic acid receptor-related orphan nuclear receptor; Foxp3, forkhead box P3; STAT, signal transducer and activator of transcription; ptpn1, protein tyrosine phosphatase, non-receptor type 1; PPAR peroxisome proliferator-activated receptor; ARE, androgen response element; ILC, innate lymphoid cell.

Androgens, such as dihydrotestosterone (DHT) or testosterone, are synthesized in the gonads and adrenal glands. Testosterone is the most concentrated androgen in adult male serum. DHT is present at one-tenth the concentration of testosterone though DHT is more potent than testosterone. Testosterone can be aromatized to E2 by aromatase. Androgens mainly bind intracellular androgen receptors (ARs) but also bind plasma membrane G-protein-coupled receptors [56].

Androgens are mostly immunosuppressive [51,57]. Androgens inhibit Th1 differentiation: testosterone inhibited IL-12-induced phosphorylation of STAT4 in murine CD4+T cells by inducing the expression of protein tyrosine phosphatase nonreceptor 1, which inactivates Jak2 and Tyk2 kinases [47]. DHT inhibited IFN- $\gamma$ production in murine CD4+T cells by enhancing the expression of peroxisome proliferator-activated receptor $\alpha(\operatorname{PPAR} \alpha)$, which represses IFN $\gamma$ transcription [48].

Androgens inhibit Th2 differentiation: DHT treatment of bone-marrow-derived dendritic cells pulsed with Trichuris muris antigen reduced their Th2-priming activity with a complete ablation of IL-4, IL-10, and IL-13 production by co-cultured T cells [54]. DHT treatment of prostate stromal 
cells suppressed the production of IL-4, IL-5, and IL-13 production by co-cultured CD4+ T cells [50]. Gonadectomized male mice showed increased IL-13-producing innate lymphoid cell 2 (ILC2) and Th2 cells and increased serum IgE levels compared to sham-operated mice in response to house dust mite antigens [53], indicating the suppressive effects of androgens on type 2 immune responses. In male castrated phospholipase A-sensitized allergic rhinitis model mice, testosterone administration decreased the production of phospholipase A-specific IgE [52], indicating the suppressive effects of androgens on allergic rhinitis. Androgens also suppress B cell lymphopoiesis [51]: testosterone acted on bone marrow stromal cells to induce the production of transforming growth factor- $\beta$, which reduced the production of IL-7 required for B cell proliferation and differentiation [56].

Androgens suppress Th17 differentiation: male gonadectomized mice showed increased IL-17A-producing Th17 and $\gamma \delta \mathrm{T}$ cells compared to sham-operated mice in response to house dust mite antigens [53]. The deficiency of AR signaling enhanced IL-17A production and IL-23R expression in T cells under Th17-differentiation conditions [53]. These results indicate the inhibitory effects of androgens on type 17 immune responses. Testosterone treatment of murine $\mathrm{T}$ cells in vitro decreased IFN- $\gamma$ or IL-17 production under the Th1- or Th17-differentiation conditions, respectively [49].

On the other hand, androgens induce Tregs: androgen-activated AR bound androgen response elements on the Foxp3 promoter and enhanced the acetylation of histone $\mathrm{H} 4$ on the promoter, allowing the binding of additional transcription factors, and thus enhanced the expression of Foxp3 in human T cells [55]. Danazol, an attenuated androgen, increased CD4+CD25highCD127lowFoxp3+ Tregs in patients with aplastic anemia [58].

\subsection{DHEA (Table 5)}

Table 5. Summary of the effects of dehydroepiandrosterone (DHEA) on the activities of T helper 1 cell (Th1), Th2, Th17, and regulatory T cell (Treg).

\begin{tabular}{|c|c|c|c|c|}
\hline Effects & Vivo/Vitro & Species & Th Activities & References \\
\hline \multicolumn{5}{|c|}{ Adaptive Immunity } \\
\hline IFN- $\gamma \uparrow$ & vivo & mice & Th1 $\uparrow$ & [59] \\
\hline IFN- $\gamma \uparrow$ & ex vivo & mice & Th1 $\uparrow$ & [60] \\
\hline IFN- $\gamma \uparrow$ & vitro & mice & Th1 $\uparrow$ & [19] \\
\hline 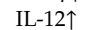 & vitro & mice & Th1 $1 \uparrow$ & [10] \\
\hline IFN- $\gamma \downarrow$ & vivo & mice & Th1 $\downarrow$ & {$[61]^{*}$} \\
\hline IFN- $\gamma \downarrow$ & vivo & mice & Th1 $\downarrow$ & {$[62]$} \\
\hline IL- $4 \downarrow$ & vivo & mice & Th2 $2 \downarrow$ & [59] \\
\hline IL-4 $\downarrow$ & vitro & mice & Th2 $2 \downarrow$ & [63] \\
\hline IL-4」 & vitro & human & Th2 $2 \downarrow$ & [64] \\
\hline $\mathrm{IL}-4 \downarrow$ & vivo & mice & Th2 $2 \downarrow$ & {$[61]^{*}$} \\
\hline IL- $4 \downarrow$ & vivo & mice & Th2 $2 \downarrow$ & [60] \\
\hline IL- $4 \downarrow$ & ex vivo & mice & Th2 $\downarrow$ & [60] \\
\hline IL-5」 & vivo & mice & Th2 $2 \downarrow$ & [59] \\
\hline 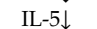 & vivo & mice & Th2 $2 \downarrow$ & [62] \\
\hline 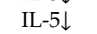 & vitro & human & Th2 $2 \downarrow$ & [64] \\
\hline 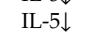 & ex vivo & mice & Th2 $2 \downarrow$ & {$[60]$} \\
\hline IL-13\ & vivo & mice & Th2 $\downarrow$ & [59] \\
\hline CCL11 $\downarrow$ & vivo & mice & Th2 $2 \downarrow$ & [59] \\
\hline CCL24 $\downarrow$ & vivo & mice & Th2 $2 \downarrow$ & [59] \\
\hline $\begin{array}{l}\text { B cell } \\
\operatorname{IgE} \downarrow\end{array}$ & vivo & mice & Th2 $2 \downarrow$ & [65] \\
\hline $\begin{array}{l}\text { B cell } \\
\text { IgE } \downarrow\end{array}$ & vivo & mice & Th2 $2 \downarrow$ & [60] \\
\hline $\begin{array}{l}\text { B cell } \\
\text { IgG1 }\end{array}$ & vivo & mice & & [60] \\
\hline IL-13个 & vivo & mice & Th2 $2 \uparrow$ & {$[62]$} \\
\hline RORC $\downarrow$ & vivo & mice & Th17 $\downarrow$ & [61] * \\
\hline IL-17A $\downarrow$ & vivo & mice & 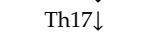 & {$[61]^{*}$} \\
\hline IL-17A $\downarrow$ & vivo & mice & 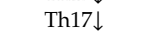 & {$[62]$} \\
\hline TNF- $\alpha \downarrow$ & vivo & mice & 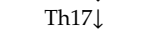 & [60] \\
\hline 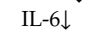 & vivo & mice & 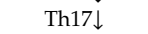 & [62] \\
\hline TGF $\beta \downarrow$ & vivo & mice & 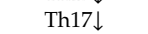 & {$[62]$} \\
\hline TNF- $\alpha \uparrow$ & vitro & human & Th17^ & {$[66]^{+}$} \\
\hline $\mathrm{IL}-6 \uparrow$ & vitro & human & Th17^ & {$[66]^{\dagger}$} \\
\hline $\mathrm{IL}-1 \beta \uparrow$ & vitro & human & Th17^ & {$[66]^{\dagger}$} \\
\hline Foxp $3 \downarrow$ & vitro & human & Treg $\downarrow$ & {$[67]$} \\
\hline 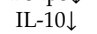 & vitro & mice & Treg $\downarrow$ & [62] \\
\hline 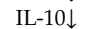 & vitro & mice & Treg $\downarrow$ & [63] \\
\hline Foxp3个 & vivo & mice & Treg $\uparrow$ & {$[68]^{* *}$} \\
\hline IL-10个 & vivo & mice & Treg $\uparrow$ & {$[61]^{*}$} \\
\hline
\end{tabular}


Table 5. Cont.

\begin{tabular}{|c|c|c|c|c|}
\hline Effects & Vivo/Vitro & Species & Th Activities & References \\
\hline \multicolumn{5}{|c|}{ Innate Immunity } \\
\hline $\begin{array}{c}\text { Mast cell } \\
\text { infiltration } \downarrow\end{array}$ & vivo & mice & Th2 $\downarrow$ & [60] \\
\hline $\begin{array}{c}\text { Eosinophil } \\
\text { infiltration } \downarrow\end{array}$ & vivo & mice & 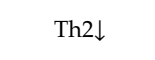 & [59] \\
\hline $\begin{array}{c}\text { Eosinophil } \\
\text { infiltration } \downarrow\end{array}$ & vivo & mice & Th2 2 & [60] \\
\hline $\begin{array}{l}\text { HaCat cells } \\
\text { CCL17 }\end{array}$ & vitro & human & Th2 $\downarrow$ & [60] \\
\hline $\begin{array}{l}\text { HaCat cells } \\
\text { CCL22 }\end{array}$ & vitro & human & Th2 $2 \downarrow$ & [60] \\
\hline $\begin{array}{l}\text { BEAS-2B } \\
\text { CCL11 }\end{array}$ & vitro & human & 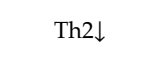 & [59] \\
\hline $\begin{array}{l}\text { BEAS-2B } \\
\text { CCL24 }\end{array}$ & vitro & human & Th2 $\downarrow$ & [59] \\
\hline $\begin{array}{c}\text { Ovary granulosa } \\
\text { cell } \\
\text { ICAM1/VCAM1 } \uparrow\end{array}$ & vivo & mice & & [19] \\
\hline
\end{tabular}

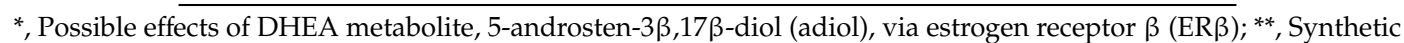
DHEA analog HE3286; $\dagger$, Effects via ER; $\uparrow$, stimulation; $\downarrow$, suppression; ?, ambiguous; ROR, retinoic acid receptor-related orphan nuclear receptor; Foxp3, forkhead box P3; ICAM1, intercellular adhesion molecule 1; VCAM1, vascular cell adhesion molecule 1.

DHEAS is the most abundant steroid in human blood serum and is secreted by the adrenal cortex [69]. DHEAS is converted by steroid sulfatase to an active form, DHEA [69]. Steroid sulfatase is controlled by an X-linked gene that escapes the Lyon effect of X-inactivation; as a result, women have twice the amount of steroid sulfatase than men [70], especially in peripheral lymphoid organs [20]. The DHEA/DHEAS ratio in circulation is usually higher in women than in men [71], and under 50 years old, the plasma DHEA concentration of women is higher than that of men [72]. It is thus hypothesized that women might be more susceptible to the effects of DHEA than men [20] though the effects might be influenced by other factors such as receptor and downstream pathways. DHEA itself binds nuclear steroid hormone receptors like AR, ER $\alpha$, or ER $\beta$ with lower affinities than cognate ligands. DHEA is metabolized to other steroid hormones, testosterone, DHT, or E2 (Figure 3), and these metabolites bind the corresponding steroid receptors: DHEA metabolite 5-androsten-3 $\beta, 17 \beta$-diol can bind ER $\beta$ [61]. Moreover, recent studies revealed that DHEA and DHEAS act as ligands of many nuclear receptors like PPAR $\alpha$, pregnane $X$ receptor, and constitutive androstanol receptor and membrane receptors like TrkA, N-methyl-D-aspartic acid receptors, or $\gamma$-amino butyric acid receptors [73]. Thus, the biological effects of DHEA depend on the levels of metabolizing enzymes and individual receptors and, thus, vary with species, tissues, or cell types.

DHEA mostly enhances Th1 differentiation: DHEA treatment enhanced IL-12 and IFN- $\gamma$ production in female murine peritoneal cells in vivo and enhanced the expression of very late antigen-4 and leukocyte function-associated antigen-1 in CD4+ T cells in vitro [19]. DHEA in vivo increased the expression of vascular cell adhesion molecule- 1 and intercellular adhesion molecule-1 in ovary granulosa cells of mice [19,74]. DHEA suppresses type 2 immune responses [65]: in female ovalbumin-sensitized asthma model mice, DHEA administration reduced eosinophil infiltration into the lung; serum ovalbumin-specific IgE levels; and the expression of IL-4, IL-5, and IL-13 and type 2 chemokines CC-chemokine ligand 1 (CCL1) and CCL24 in bronchoalveolar lavage fluid but increased IFN- $\gamma$ production in ovalbumin-activated splenocytes [59]. DHEA reduced IL-4 production but increased IL-2 production in concanavalin A-stimulated human PBMCs [64]. In LPS-induced experimental inflammation model mice, DHEA increased the Th1/Th2 ratio in spleen T cells [63]. DHEA significantly increased Th1 cytokine levels (IL-2 and IFN- $\alpha$ ) and decreased Th2 cytokine levels (IL- 4 and IL-10) in primary cultured spleen T cells [63]. DHEA decreased $\mathrm{Na}^{+} \mathrm{K}^{+}$-ATPase activity and increased $\mathrm{Ca}^{2+}$ ATPase activity in $\mathrm{T}$ cells, which might regulate the balance of cytokine secretion [63]. Thus, DHEA enhances Th1 immune response and regulates the balance of Th1/Th2 toward Th1-dominant immunity. In AD model mice induced by topical 2,4-dinitrochlorobenzene (DNCB), oral or topical 
DHEA attenuated the infiltration of eosinophils and mast cells into DNCB-challenged ear skin. In those mice, oral or topical DHEA also reduced serum IL-4 and IgE levels and reduced IL-4 and IL-5 production but increased IFN- $\gamma$ production in splenocytes [60]. DHEA in vitro suppressed the production of type 2 chemokines, CCL17 and CCL22, in tumor necrosis factor- $\alpha$-stimulated HaCat cells [60].

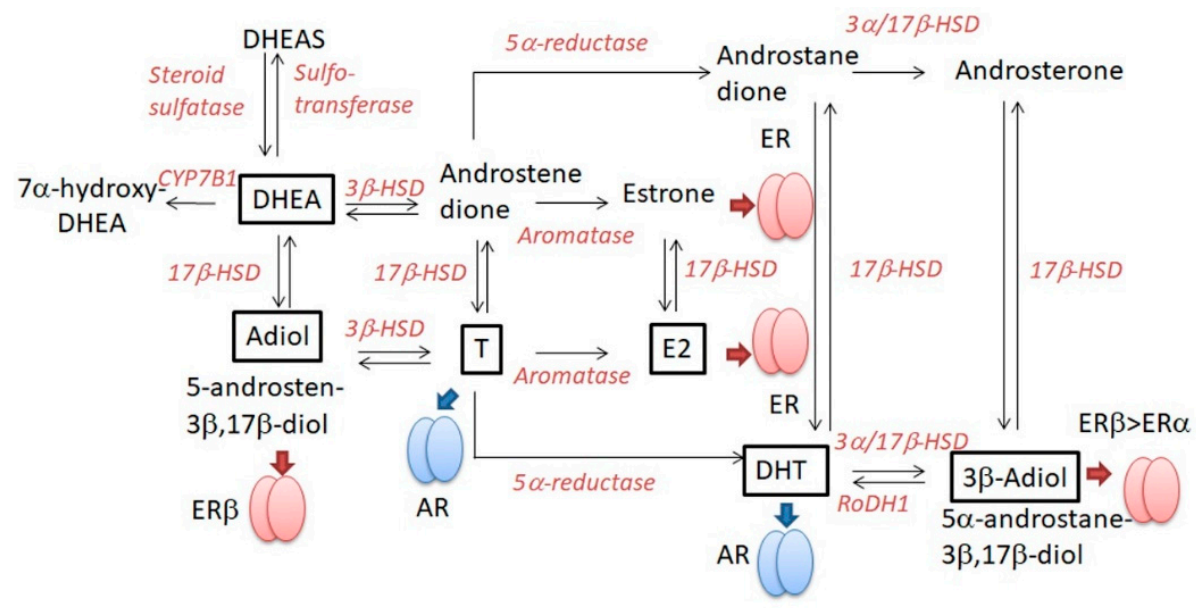

Figure 3. Dehydroepiandrosterone (DHEA) metabolizing pathway. DHEAS, dehydroepiandrosterone sulfate; DHT, dihydrotestosterone; T, testosterone; E2, estradiol; AR, androgen receptor; ER, estrogen receptor; $17 \beta$-HSD, $17 \beta$-hydroxysteroid dehydrogenase; RoDH1, retinol dehydrogenase type $1 ; \downarrow$, binding to the steroid receptor described.

The effects of DHEA on Th17 and Treg are ambiguous [62] and dependent on tissue or disease context [66]: DHEA treatment increased the number of Foxp3+ Tregs in splenocytes of female ovariectomized mice [75]. In EAE model mice and human multiple sclerosis patients, DHEA directly inhibited the activity of Th17 cells, inducing IL-10-producing Tregs via ER $\beta$ activation [61]. This effect may be mediated by 5 -androsten-3 $\beta, 17 \beta$-diol, converted from DHEA by $17 \beta$-hydroxysteroid dehydrogenase (Figure 3). Synthetic DHEA analog HE3286 increased the frequency of CD4+CD25+Foxp3+ Tregs in spleen in collagen-induced arthritis model mice [68] though the receptors for this analog are unknown and not $E R \alpha, E R \beta$, or AR. In contrast, DHEA reduced the expression of Foxp3 without altering Treg frequency in PBMCs from patients co-infected with HIV and tuberculosis [67].

\section{The Effects of Sex Hormones on the Skin Barrier (Table 1)}

Overall, in adults, skin hydration is slightly higher in women than in men and basal transepidermal water loss (TEWL) is significantly higher in men than in women [35,76]. The epidermal permeability barrier is impaired by androgens and progesterone but is restored by E2 [77]. E2 paradoxically worsens the progesterone-induced barrier impairment [78]. The skin barrier is impaired in the luteal phase when both progesterone and estrogen are secreted [79].

The ovariectomy of female C57/BL6 mice reduced skin hydration, delayed skin permeability recovery after tape stripping, and reduced epidermal thickness; these were restored by the administration of E2 [80]. Ovariectomy also reduced the expression of desmoglein-1, involucrin, and loricrin, key constituents of corneodesmosome and cornified envelope (CE) in SC; these were restored by E2 treatment [80]. Ovariectomy of female nude mice (ICR-Foxn1nu) also reduced the expression of filaggrin and integrin $\beta$ in the skin [81]. These results support that $\mathrm{E} 2$ strengthens the skin permeability barrier and integrity.

The castration of male mice (Sk:h1) or treatment with AR antagonist flutamide accelerated skin permeability recovery after tape stripping, and testosterone administration delayed recovery in the castrated mice [82]. Testosterone treatment of castrated mice reduced the number of lamellar bodies in 
the cytosol of stratum granulosum (SG) cells and decreased secreted lamellar contents at the interface of SC and SG [82]. These results support that testosterone perturbs the skin permeability barrier homeostasis. The administration of E2 in pregnant rats reduced TEWL of day-20 fetus while that was increased by DHT [77]. The administration of E2 accelerated lipid deposition and formation of lamellar unit structures in the SC of day-20 fetal epidermis in utero while these were delayed by DHT [77]. In fetal skin explants from day-17 rats, estrogen increased while DHT reduced the activity of $\beta$-glucocerebrosidase, which converts glucosylceramides to ceramides and is essential for the formation of lamellar unit structures throughout SC interstices [83]. In the same explants, estrogen accelerated while DHT delayed the expression of filaggrin and loricrin, key constituents of keratohyalin granules and CE, respectively [84]. These results indicate that E2 accelerates while androgen delays SC barrier formation.

Topical testosterone delayed skin permeability barrier recovery in male hairless mice (HR-1), and the delay was overcome by co-application of E2 [78]. Progesterone also delayed the recovery; however, the delay was paradoxically enhanced by E2 [78]. To date, the precise mechanism of how progesterone delays skin permeability barrier recovery is not elucidated; however, it is indicated that progesterone opposes the protective effect of E2 on skin permeability barrier and that the skin permeability barrier may be impaired in females in the luteal phase when both progesterone and estrogen are secreted. Muizzuddin et al. showed that the skin permeability barrier was the weakest between days 22 and 26 of the menstrual cycle, the mid-luteal phase [85]. TEWL is higher at the day of minimal estrogen/progesterone ratio (around day 26) than that at the day of maximal estrogen secretion (around day 13) [79]. It is thus hypothesized that the skin barrier might be protected by E2, which might be opposed by progesterone. The skin patch test reaction to Ni is higher at the luteal phase than that at the ovulatory phase or at the follicular phase [86], which may be due to the skin permeability barrier impairment at the luteal phase when progesterone is secreted. In the uterus of ovariectomized mice, E2 treatment increased mRNA levels of small proline-rich protein 2 (SPRR2), which was dampened by progesterone [87]. Since SPRRs are key constituents of CE in SC of the skin, further studies should elucidate if such suppressive effects of progesterone might be reproduced in the skin. In contrast, progesterone upregulated the expression of TJ proteins occludin and zona occludens 2 in the epidermis, and this effect was canceled by E2 in ovariectomized FvB mice [88]. Progesterone upregulated the expression of occludin in human gut tissues and Caco-2 cells [89]. It is thus hypothesized that the TJ barrier might be restored by progesterone but impaired by E2, opposite to the SC barrier, though confirmative studies are required for its verification.

It is reported that oral DHEA in humans at $>60$ years old improved skin hydration, epidermal thickness, sebum production, and pigmentation [90]. Such antiaging effects of DHEA are mainly generated by the enhanced collagen biosynthesis and deposition: topical DHEA increased the mRNA levels of procollagen $1 / 3$ and heat shock protein 47 , a type 1 collagen chaperone protein in human dermal fibroblasts [91]. In contrast, topical DHEA treatment reduced the expression of genes associated with the terminal differentiation and cornification of keratinocytes, corneodesmosin, claudin 8, SPRR2G, late envelope protein 7 , and Jagged 1, indicating the suppression of skin barrier properties [92]. To date, the direct effects of DHEA on skin permeability barrier have not been reported and should further be examined. In the testis, DHEAS but not DHEA augmented the TJ connections between Sertoli cells by promoting the expression of claudin- 3 and -5 via membrane $\mathrm{Gn}_{\alpha 11}$-coupled receptors independent of AR [93].

\section{The Effects of Sex Hormones on the Pruritus}

There have been no reports that sex hormones act as pruritogens. However, E2 and/or progesterone directly or indirectly induce the secretion of Th2-related cytokines, IL-4, IL-13, IL-31, TSLP, or IL-33; these cytokines bind the corresponding receptors on C-type sensory neurons and generate an itch sensation [94]. In Th2 hapten TDI-sentitized allergic dermatitis model mice, oral or topical administration of ER $\alpha$ agonist propylpyrazoletriol induced TSLP and IL-33 expression in keratinocytes 
and promoted scratching behavior [95]; the pruritus might be caused by TSLP and IL-33. Estrogen also acted on mast cells and promoted the release of histamines [33,37], which also act as pruritogens.

In sensory neuron-keratinocyte coculture model, DHEA produced by keratinocytes promoted neurite growth possibly through the activation of TrkA [96,97], indicating the relations to abnormal neurite outgrowth into the epidermis of AD lesions. The effects of sex hormones on neurite growth should further be examined precisely.

\section{Intrinsic AD}

Intrinsic $\mathrm{AD}$ patients occupy around $10-20 \%$ of whole $\mathrm{AD}$, show normal $\operatorname{IgE}$ values, lack IgE antibodies against environmental or food allergens, and lack barrier disruption and filaggrin gene mutation [15]. Intrinsic AD patients manifest Dennie-Morgan fold but without icthyosis vulgaris and palmar hyperlinearity and with milder severity of AD. Intrinsic AD patients show positive on patch tests to metals, especially to $\mathrm{Ni}$, at a higher percentage than extrinsic $\mathrm{AD}$ patients, indicating the higher incidence of metal allergy [98]. Intrinsic AD patients show high $\mathrm{Ni}$ concentrations in serum and sweat $[98,99]$, indicating the enhanced absorption and/or transport of $\mathrm{Ni}$ derived from food and sensitization with $\mathrm{Ni}$ in the circulation and skin. Immunologically, intrinsic AD patients show higher Th1 activity than that of extrinsic AD patients and show Th2 activity comparable to that of extrinsic AD patients [100]. Since Ni interacts with toll-like receptor 4 in addition to major histocompatibility/self-peptide complex and induces a mixed Th1 and Th2 cytokine responses [98,101-103], a considerable number of intrinsic AD patients, though not all, might show both Th1 and Th2 responses to Ni through its presentation by antigen presenting cells in the skin patch test. Thus, metals might act as the main allergens in intrinsic AD though other agents might also work in its pathogenesis. In both children or adults, the prevalence of intrinsic $A D$ is higher in females than in males [104,105]; moreover, the prevalence of Ni allergy is higher in females than in males [106,107].

\section{Possible Hypotheses on the Generation-Dependent Sexual Difference in the Prevalence of Extrinsic AD (Table 6)}

It is hypothesized that prepubertal children might be mostly devoid of the influence of sex hormones considering their very low concentrations. The effects of DHEA, shifting the Th1/Th2 balance to Th1, might be more remarkably revealed in girls than in boys due to the higher levels of steroid sulfatase converting DHEAS to DHEA. Thus, both atopic asthma and extrinsic AD, Th2-shifted allergic diseases with atopic diathesis, might be more prevalent in boys than in girls. The male preponderance in childhood asthma might also involve gender-specific factors other than hormonal regulation [108]: boys have smaller airway diameters relative to lung volume (dysanapsis; [109]) and show a higher percentage of positive skin prick tests or IgE antibodies against aeroallergens than girls, indicating higher atopic diathesis in boys than in girls [110]. The higher aeroallergen sensitivities in boys may also be related to the male predominance in childhood AD [111]. Alternatively, the higher asthma incidence in boys may be because underdiagnosed and undertreated asthma patients exist among girls [112].

After puberty, the levels of sex hormones, estrogen, progesterone, testosterone, or DHT are greatly increased and individuals might thus be more greatly influenced by the immunological effects of those sex hormones than those of DHEA $[18,113,114]$. Women are exposed to higher levels of estrogen and progesterone promoting Th2 activity. The prevalence and severity of atopic asthma might thus become much higher in women than in men exposed to higher levels of androgens suppressing Th2 activity. The female preponderance in adult asthma may also involve other gender-specific factors [108]: the bronchial hyperresponsiveness is more frequent in women than in men; women are more likely to be exposed to indoor aeroallergens than men.

In the case of adult extrinsic $\mathrm{AD}$, patients are influenced by the effects of sex hormones both on immune responses and skin barrier impairment. The Th2 shift is more prevalent in women than in men; however, skin barrier impairment is more likely to occur in men exposed to high levels of androgens perturbing skin permeability barrier. In women, skin barrier is restored by estrogen at 
the follicular and ovulatory phases but are disturbed by progesterone at the luteal phase. Totally, female adults might be slightly more protected from skin barrier impairment compared to male adults, considering the postmenopausal skin barrier disruption in females and its restoration by hormonal agents, including both estrogen and progesterone [115]. Thus, female adults with higher Th2 activity but slightly more protection from skin barrier impairment may show a slightly higher prevalence of extrinsic AD compared to male adults, though the sexual difference is moderate compared to strict female preponderance of adult atopic asthma. It is known that Th1 activity is enhanced in the chronic phase of $\mathrm{AD}$ and that Th17 cells may also be involved in the pathogenesis of $\mathrm{AD}$ [5], which might be more applicable to women than men since estrogen might promote Th1 and Th17 activities at estrous level of concentrations [21]. Other gender-specific factors might also be related to the moderate female preponderance of adult AD: women are more responsive to pruritogens than men, and female mice showed higher scratching counts than male mice under the stimulus of proteinase-activated receptor-2-activating peptide [116]. The involvement of sex hormones in hyperknesis or alloknesis should further be investigated.

Table 6. The generation-dependent sexual difference in the prevalence of atopic asthma and extrinsic atopic dermatitis (AD).

\begin{tabular}{|c|c|c|c|c|c|c|}
\hline & \multicolumn{3}{|c|}{ Child } & \multicolumn{3}{|c|}{ Adolescent-Adult } \\
\hline $\begin{array}{l}\text { Atopic } \\
\text { Asthma }\end{array}$ & $\begin{array}{c}\text { Atopic } \\
\text { Diathesis }\end{array}$ & & $\begin{array}{c}\text { Th2 } \\
\text { Regulation } \\
\text { by DHEA }\end{array}$ & $\begin{array}{c}\text { Th2 } \\
\text { Regulation } \\
\text { by Sex } \\
\text { Hormones }\end{array}$ & $\begin{array}{c}\text { Th2 } \\
\text { Regulation } \\
\text { by DHEA }\end{array}$ & \\
\hline $\begin{array}{l}\mathrm{M} \\
\mathrm{F}\end{array}$ & $\begin{array}{c}+\sim++ \\
+\end{array}$ & & $\stackrel{\downarrow}{\downarrow \downarrow}$ & $\begin{array}{c}\downarrow \downarrow \downarrow \text { by A } \\
\uparrow \uparrow \uparrow \uparrow \text { by E, P }\end{array}$ & $\underset{\downarrow}{\downarrow}$ & \\
\hline Prevalence & \multicolumn{3}{|c|}{$M>F$} & \multicolumn{3}{|c|}{$\mathrm{M} \ll \mathrm{F}$} \\
\hline $\begin{array}{c}\text { Extrinsic } \\
\text { AD }\end{array}$ & $\begin{array}{c}\text { Atopic } \\
\text { Diathesis }\end{array}$ & $\begin{array}{l}\text { Filaggrin } \\
\text { Gene } \\
\text { Nutation }\end{array}$ & $\begin{array}{c}\text { Th2 } \\
\text { Regulation } \\
\text { by DHEA }\end{array}$ & $\begin{array}{c}\text { Th2 } \\
\text { Regulation } \\
\text { by Sex } \\
\text { Hormones }\end{array}$ & $\begin{array}{c}\text { Th2 } \\
\text { Regulation } \\
\text { by DHEA }\end{array}$ & $\begin{array}{c}\text { Skin Barrier } \\
\text { Impairment } \\
\text { by Sex } \\
\text { Hormones }\end{array}$ \\
\hline $\mathrm{M}$ & $+\sim++$ & + or - & $\downarrow$ & $\downarrow \downarrow$ by A & $\downarrow$ & $\uparrow$ by A \\
\hline $\mathrm{F}$ & + & + or - & $\downarrow \downarrow$ & $\uparrow \uparrow \uparrow \uparrow$ by E, P & $\downarrow \downarrow$ & $\begin{array}{c}\downarrow \downarrow \text { by E } \uparrow \text { by } P \\
\text { Totally } \downarrow\end{array}$ \\
\hline Prevalence & & $\mathrm{M}>\mathrm{F}$ & & & $\mathrm{M}<\mathrm{F}$ & \\
\hline
\end{tabular}

$\uparrow$, Stimulation; $\downarrow$, Suppression; Th2, T helper 2 cell; DHEA, dehydroepiandrosterone; F, female; M, male; A, androgen; E, estrogen; $\mathrm{P}$, progesterone.

\section{Possible Hypotheses on Female Preponderance of Intrinsic AD (Table 7)}

We herein propose a hypothesis on female preponderance of intrinsic AD in the context of metal allergy, one possible agent of its pathogenesis. Patients with intrinsic AD are not associated with atopic diathesis, filaggrin gene mutation, or congenital skin barrier impairment and are associated with enhanced Th1 activity as well as Th2 and high incidence of Ni allergy though not in all patients. Before puberty, there is no sexual difference in the chances of Ni exposure, though in Western countries, girls are more frequently exposed to Ni due to the first pierce experiences. Th1 responses to Ni might be more remarkable in girls with higher susceptibility to DHEA promoting Th1 activity than in boys. Totally, intrinsic AD in childhood might be more prevalent in girls than in boys.

After puberty, women are more frequently exposed to $\mathrm{Ni}$ by wearing ornaments than men. The immune response to Ni might be gradually shifted from Th1 to Th2 since repeated elicitation with antigens alters the balance of cytokines released locally, with a shift toward Th2-dominated responses [117]. Immune responses after puberty might be more susceptible to the influence of sex hormones than of DHEA. After puberty, Th2 responses to Ni might be more remarkable in women with higher levels of estrogen and progesterone stimulating Th2 activity than men with higher levels of androgens suppressing Th2 activity. The intrinsic AD after puberty might thus become much more 
prevalent in women than in men. The female preponderance of intrinsic AD may also involve certain gender-dependent factors unrelated to metal allergy, which should further be identified.

Table 7. Female preponderance of intrinsic atopic dermatitis (AD).

\begin{tabular}{|c|c|c|c|c|c|c|c|}
\hline \multirow[b]{2}{*}{$\begin{array}{c}\text { Intrinsic } \\
\text { AD }\end{array}$} & \multicolumn{4}{|c|}{ Child } & \multicolumn{3}{|c|}{ Adolescent-Adult } \\
\hline & $\begin{array}{c}\text { Atopic } \\
\text { Diathesis }\end{array}$ & $\begin{array}{l}\text { Filaggrin } \\
\text { Gene } \\
\text { Nutation }\end{array}$ & $\begin{array}{l}\text { Exposure } \\
\text { to } \mathrm{Ni}\end{array}$ & $\begin{array}{l}\text { Stimulation } \\
\text { of Th1 } \\
\text { Response to } \\
\text { Ni by DHEA } \\
\end{array}$ & $\begin{array}{l}\text { Exposure } \\
\text { to } \mathrm{Ni}\end{array}$ & $\begin{array}{c}\text { Regulation of } \\
\text { Th2 Response } \\
\text { to Ni by Sex } \\
\text { Hormones }\end{array}$ & 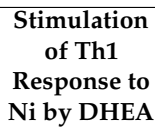 \\
\hline $\mathrm{M}$ & - & - & + & $\uparrow$ & + & $\downarrow \downarrow$ by A & $\uparrow$ \\
\hline F & - & - & $+\sim++$ & $\uparrow \uparrow$ & ++ & $\uparrow \uparrow \uparrow \uparrow$ by E, P & $\uparrow \uparrow$ \\
\hline Prevalence & & & $<\mathrm{F}$ & & & $\mathrm{M} \ll \mathrm{F}$ & \\
\hline
\end{tabular}

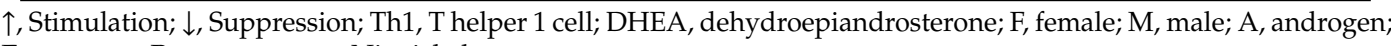
E, estrogen; $\mathrm{P}$, progesterone; $\mathrm{Ni}$, nickel.

\section{Possible Hypotheses on the Premenstrual Deterioration of AD in Females}

About half of female AD patients experience premenstrual deterioration of AD symptoms [118]. The deterioration might be due to the dual effects of estrogen and progesterone on Th2 activity and skin barrier. At the luteal phase, both estrogen and progesterone are secreted and, thus, Th2-skewing effects are higher than in the other phases; moreover, the skin permeability barrier is perturbed by progesterone, especially, just prior to menstruation with minimal estrogen/progesterone ratio.

The deterioration of $\mathrm{AD}$ during pregnancy is also reported; $52 \%$ or $61 \%$ of female $\mathrm{AD}$ patients who experienced pregnancy had noticed deterioration of AD during pregnancy in the UK [119] or Korea [120], respectively. The deterioration of AD during pregnancy might also reflect the effects of extremely high concentrations of E2 and progesterone on Th2 activity and skin barrier. Moreover, the prevalence of deterioration during pregnancy was higher in intrinsic AD patients (100\%) compared to that in extrinsic AD patients (47.1\%) in the Korean study [120]. It is thus hypothesized that intrinsic $\mathrm{AD}$ patients might be more susceptible to the influence of female sex hormones compared to extrinsic AD patients.

\section{Serum Hormone Concentrations in Patients with Allergic Diseases}

It is reported that serum concentrations of DHEA or testosterone are lower in male AD patients compared to the reference group [64,121]. These indicate that DHEA- or testosterone-induced suppressive effects on Th2 activity are reduced in male AD patients, which might aggravate the symptoms of AD. It is also reported that serum concentrations of DHEA or DHEAS are lower in patients with asthma or chronic spontaneous urticaria compared to the reference group, irrespective of gender [122]. It is thus speculated that the reduction of Th2-suppressive effects by DHEA might accelerate the Th2 shift in these patients though confirmatory studies are needed to verify the speculation.

It is reported that prolonged physical stress with energy and sleep deprivation reduced serum DHEA levels and increased serum DHEAS levels, indicating the decrease of steroid sulfatase activity and/or increase of sulfotransferase activity by prolonged physical stress [123]. It is thus hypothesized that the reduction of DHEA levels might be one possible cause of the stress-induced exacerbation of allergic diseases.

\section{Conclusions}

We reviewed the effects of sex hormones related to the course of AD and focused on immune responses and skin barrier. The balance of the effects of sex hormones might up- or downregulate the prevalence and course of AD. Future studies should elucidate the effects of sex hormones on Th22 activity or pruritus, using AD model mice.

Author Contributions: N.K. is the main author in manuscript drafting; T.H. revised the bibliography and updated the figures and tables; H.S. made a critical revision of the manuscript. 
Funding: This research received no external funding.

Conflicts of Interest: The authors declare no conflict of interest.

\section{References}

1. Furue, M.; Chiba, T.; Tsuji, G.; Ulzii, D.; Kido-Nakahara, M.; Nakahara, T.; Kadono, T. Atopic dermatitis: Immune deviation, barrier dysfunction, IgE autoreactivity and new therapies. Allergol. Int. 2017, 66, 398-403. [CrossRef] [PubMed]

2. Furue, M.; Ulzii, D.; Vu, Y.H.; Tsuji, G.; Kido-Nakahara, M.; Nakahara, T. Pathogenesis of Atopic Dermatitis: Current Paradigm. Iran. J. Immunol. 2019, 16, 97-107. [CrossRef] [PubMed]

3. Egawa, G.; Kabashima, K. Barrier dysfunction in the skin allergy. Allergol. Int. 2018, 67, 3-11. [CrossRef] [PubMed]

4. Yuki, T.; Tobiishi, M.; Kusaka-Kikushima, A.; Ota, Y.; Tokura, Y. Impaired tight junctions in atopic dermatitis skin and in a skin-equivalent model treated with interleukin-17. PLoS ONE 2016, 11, e0161759. [CrossRef] [PubMed]

5. Nomura, T.; Honda, T.; Kabashima, K. Multipolarity of cytokine axes in the pathogenesis of atopic dermatitis in terms of age, race, species, disease stage and biomarkers. Int. Immunol. 2018, 30, 419-428. [CrossRef] [PubMed]

6. Dirven-Meijer, P.C.; Glazenburg, E.J.; Mulder, P.G.; Oranje, A.P. Prevalence of atopic dermatitis in children younger than 4 years in a demarcated area in central Netherlands: The West Veluwe Study Group. Br. J. Dermatol. 2008, 158, 846-847. [CrossRef] [PubMed]

7. Saeki, H.; Tsunemi, Y.; Fujita, H.; Kagami, S.; Sasaki, K.; Ohmatsu, H.; Watanabe, A.; Tamaki, K. Prevalence of atopic dermatitis determined by clinical examination in Japanese adults. J. Dermatol. 2006, 33, 817-819. [CrossRef]

8. Harrop, J.; Chinn, S.; Verlato, G.; Olivieri, M.; Norback, D.; Wjst, M.; Janson, C.; Zock, J.P.; Leynaert, B.; Gislason, D.; et al. Eczema, atopy and allergen exposure in adults: A population-based study. Clin. Exp. Allergy 2007, 37, 526-535. [CrossRef]

9. Chen, W.; Mempel, M.; Schober, W.; Behrendt, H.; Ring, J. Gender difference, sex hormones, and immediate type hypersensitivity reactions. Allergy 2008, 63, 1418-1427. [CrossRef]

10. Schatz, M.; Camargo, C.A., Jr. The relationship of sex to asthma prevalence, health care utilization, and medications in a large managed care organization. Ann. Allergy Asthma Immunol. 2003, 91, 553-558. [CrossRef]

11. Schatz, M.; Clark, S.; Camargo, C.A., Jr. Sex differences in the presentation and course of asthma hospitalizations. Chest 2006, 129, 50-55. [CrossRef] [PubMed]

12. Tai, P.; Wang, J.; Jin, H.; Song, X.; Yan, J.; Kang, Y.; Zhao, L.; An, X.; Du, X.; Chen, X.; et al. Induction of regulatory T cells by physiological level estrogen. J. Cell Physiol. 2008, 214, 456-464. [CrossRef] [PubMed]

13. Kuramoto, T.; Yokoe, M.; Tanaka, D.; Yuri, A.; Nishitani, A.; Higuchi, Y.; Yoshimi, K.; Tanaka, M.; Kuwamura, M.; Hiai, H.; et al. Atopic dermatitis-like skin lesions with IgE hyperproduction and pruritus in KFRS4/Kyo rats. J. Dermatol. Sci. 2015, 80, 116-123. [CrossRef] [PubMed]

14. Sengupta, P. The laboratory rat: Relating its age with human's. Int. J. Prev. Med. 2013, 4, 624-630. [PubMed]

15. Tokura, Y. Extrinsic and intrinsic types of atopic dermatitis. J. Dermatol. Sci. 2010, 58, 1-7. [CrossRef] [PubMed]

16. Farage, M.A.; Neill, S.; MacLean, A.B. Physiological changes associated with the menstrual cycle: A review. Obstet. Gynecol. Surv. 2009, 64, 58-72. [CrossRef] [PubMed]

17. Hughes, G.C. Progesterone and autoimmune disease. Autoimmun. Rev. 2012, 11, A502-514. [CrossRef]

18. Roved, J.; Westerdahl, H.; Hasselquist, D. Sex differences in immune responses: Hormonal effects, antagonistic selection, and evolutionary consequences. Horm. Behav. 2017, 88, 95-105. [CrossRef]

19. Solano, M.E.; Sander, V.A.; Ho, H.; Motta, A.B.; Arck, P.C. Systemic inflammation, cellular influx and up-regulation of ovarian VCAM-1 expression in a mouse model of polycystic ovary syndrome (PCOS). J. Reprod. Immunol. 2011, 92, 33-44. [CrossRef]

20. Namazi, M.R. The Th1-promoting effects of dehydroepiandrosterone can provide an explanation for the stronger Th1-immune response of women. Iran. J. Allergy Asthma Immunol. 2009, 8, 65-69. 
21. Xiang, Y.; Jin, Q.; Li, L.; Yang, Y.; Zhang, H.; Liu, M.; Fan, C.; Li, J.; Shan, Z.; Teng, W. Physiological low-dose oestrogen promotes the development of experimental autoimmune thyroiditis through the up-regulation of Th1/Th17 responses. J. Reprod. Immunol. 2018, 126, 23-31. [CrossRef] [PubMed]

22. Dayoub, O.; Le Lay, S.; Soleti, R.; Clere, N.; Hilairet, G.; Dubois, S.; Gagnadoux, F.; Boursier, J.; Martinez, M.C.; Andriantsitohaina, R. Estrogen receptor alpha/HDAC/NFAT axis for delphinidin effects on proliferation and differentiation of T lymphocytes from patients with cardiovascular risks. Sci. Rep. 2017, 7, 9378. [CrossRef] [PubMed]

23. Haghmorad, D.; Salehipour, Z.; Nosratabadi, R.; Rastin, M.; Kokhaei, P.; Mahmoudi, M.B.; Amini, A.A.; Mahmoudi, M. Medium-dose estrogen ameliorates experimental autoimmune encephalomyelitis in ovariectomized mice. J. Immunotoxicol. 2016, 13, 885-896. [CrossRef] [PubMed]

24. Garnier, L.; Laffont, S.; Lelu, K.; Yogev, N.; Waisman, A.; Guery, J.C. Estrogen Signaling in Bystander Foxp3(neg) CD4(+) T Cells Suppresses Cognate Th17 Differentiation in Trans and Protects from Central Nervous System Autoimmunity. J. Immunol. 2018, 201, 3218-3228. [CrossRef] [PubMed]

25. Lasarte, S.; Elsner, D.; Guia-Gonzalez, M.; Ramos-Medina, R.; Sanchez-Ramon, S.; Esponda, P.; Munoz-Fernandez, M.A.; Relloso, M. Female sex hormones regulate the Th17 immune response to sperm and Candida albicans. Hum. Reprod. 2013, 28, 3283-3291. [CrossRef] [PubMed]

26. Lambert, K.C.; Curran, E.M.; Judy, B.M.; Milligan, G.N.; Lubahn, D.B.; Estes, D.M. Estrogen receptor alpha (ERalpha) deficiency in macrophages results in increased stimulation of CD4+ T cells while 17beta-estradiol acts through ERalpha to increase IL-4 and GATA-3 expression in CD4+ T cells independent of antigen presentation. J. Immunol. 2005, 175, 5716-5723. [CrossRef] [PubMed]

27. Han, D.; Denison, M.S.; Tachibana, H.; Yamada, K. Effects of estrogenic compounds on immunoglobulin production by mouse splenocytes. Biol. Pharm. Bull. 2002, 25, 1263-1267. [CrossRef] [PubMed]

28. Iannello, A.; Rolla, S.; Maglione, A.; Ferrero, G.; Bardina, V.; Inaudi, I.; De Mercanti, S.; Novelli, F.; D'Antuono, L.; Cardaropoli, S.; et al. Pregnancy epigenetic signature in T helper 17 and T regulatory cells in multiple sclerosis. Front. Immunol. 2018, 9, 3075. [CrossRef]

29. Qin, J.; Li, L.; Jin, Q.; Guo, D.; Liu, M.; Fan, C.; Li, J.; Shan, Z.; Teng, W. Estrogen receptor beta activation stimulates the development of experimental autoimmune thyroiditis through up-regulation of Th17-type responses. Clin. Immunol. 2018, 190, 41-52. [CrossRef]

30. Adurthi, S.; Kumar, M.M.; Vinodkumar, H.S.; Mukherjee, G.; Krishnamurthy, H.; Acharya, K.K.; Bafna, U.D.; Uma, D.K.; Abhishekh, B.; Krishna, S.; et al. Oestrogen Receptor-alpha binds the FOXP3 promoter and modulates regulatory T-cell function in human cervical cancer. Sci. Rep. 2017, 7, 17289. [CrossRef]

31. Polanczyk, M.J.; Carson, B.D.; Subramanian, S.; Afentoulis, M.; Vandenbark, A.A.; Ziegler, S.F.; Offner, H. Cutting edge: Estrogen drives expansion of the CD4+CD25+ regulatory $\mathrm{T}$ cell compartment. J. Immunol. 2004, 173, 2227-2230. [CrossRef] [PubMed]

32. Polari, L.; Wiklund, A.; Sousa, S.; Kangas, L.; Linnanen, T.; Harkonen, P.; Maatta, J. SERMs Promote Anti-Inflammatory Signaling and Phenotype of CD14+ Cells. Inflammation 2018, 41, 1157-1171. [CrossRef] [PubMed]

33. Zaitsu, M.; Narita, S.; Lambert, K.C.; Grady, J.J.; Estes, D.M.; Curran, E.M.; Brooks, E.G.; Watson, C.S.; Goldblum, R.M.; Midoro-Horiuti, T. Estradiol activates mast cells via a non-genomic estrogen receptor-alpha and calcium influx. Mol. Immunol. 2007, 44, 1977-1985. [CrossRef] [PubMed]

34. Matalka, K.Z. The effect of estradiol, but not progesterone, on the production of cytokines in stimulated whole blood, is concentration-dependent. Neuro Endocrinol. Lett. 2003, 24, 185-191. [PubMed]

35. Polese, B.; Gridelet, V.; Araklioti, E.; Martens, H.; Perrier d'Hauterive, S.; Geenen, V. The Endocrine Milieu and CD4 T-Lymphocyte Polarization during Pregnancy. Front. Endocrinol. (Lausanne) 2014, 5, 106. [CrossRef] [PubMed]

36. Chen, R.Y.; Fan, Y.M.; Zhang, Q.; Liu, S.; Li, Q.; Ke, G.L.; Li, C.; You, Z. Estradiol inhibits Th17 cell differentiation through inhibition of RORgammaT transcription by recruiting the ERalpha/REA complex to estrogen response elements of the RORgammaT promoter. J. Immunol. 2015, 194, 4019-4028. [CrossRef] [PubMed]

37. Narita, S.; Goldblum, R.M.; Watson, C.S.; Brooks, E.G.; Estes, D.M.; Curran, E.M.; Midoro-Horiuti, T. Environmental estrogens induce mast cell degranulation and enhance IgE-mediated release of allergic mediators. Environ. Health Perspect. 2007, 115, 48-52. [CrossRef] [PubMed] 
38. Watanabe, Y.; Tajiki-Nishino, R.; Tajima, H.; Fukuyama, T. Role of estrogen receptors alpha and beta in the development of allergic airway inflammation in mice: A possible involvement of interleukin 33 and eosinophils. Toxicology 2019, 411, 93-100. [CrossRef] [PubMed]

39. Maeda, Y.; Ohtsuka, H.; Tomioka, M.; Oikawa, M. Effect of progesterone on Th1/Th2/Th17 and regulatory T cell-related genes in peripheral blood mononuclear cells during pregnancy in cows. Vet. Res. Commun. 2013, 37, 43-49. [CrossRef]

40. Kozma, N.; Halasz, M.; Polgar, B.; Poehlmann, T.G.; Markert, U.R.; Palkovics, T.; Keszei, M.; Par, G.; Kiss, K.; Szeberenyi, J.; et al. Progesterone-induced blocking factor activates STAT6 via binding to a novel IL-4 receptor. J. Immunol. 2006, 176, 819-826. [CrossRef] [PubMed]

41. Xu, L.; Dong, B.; Wang, H.; Zeng, Z.; Liu, W.; Chen, N.; Chen, J.; Yang, J.; Li, D.; Duan, Y. Progesterone suppresses Th17 cell responses, and enhances the development of regulatory $\mathrm{T}$ cells, through thymic stromal lymphopoietin-dependent mechanisms in experimental gonococcal genital tract infection. Microbes Infect. 2013, 15, 796-805. [CrossRef] [PubMed]

42. Miyaura, H.; Iwata, M. Direct and indirect inhibition of Th1 development by progesterone and glucocorticoids. J. Immunol. 2002, 168, 1087-1094. [CrossRef] [PubMed]

43. Hall, O.J.; Limjunyawong, N.; Vermillion, M.S.; Robinson, D.P.; Wohlgemuth, N.; Pekosz, A.; Mitzner, W.; Klein, S.L. Progesterone-Based Therapy Protects Against Influenza by Promoting Lung Repair and Recovery in Females. PLoS Pathog. 2016, 12, e1005840. [CrossRef] [PubMed]

44. Mitchell, V.L.; Gershwin, L.J. Progesterone and environmental tobacco smoke act synergistically to exacerbate the development of allergic asthma in a mouse model. Clin. Exp. Allergy 2007, 37, 276-286. [CrossRef] [PubMed]

45. Lorenz, T.K.; Heiman, J.R.; Demas, G.E. Sexual activity modulates shifts in TH1/TH2 cytokine profile across the menstrual cycle: An observational study. Fertil. Steril. 2015, 104, 1513-1521. [CrossRef]

46. Lee, J.H.; Ulrich, B.; Cho, J.; Park, J.; Kim, C.H. Progesterone promotes differentiation of human cord blood fetal T cells into T regulatory cells but suppresses their differentiation into Th17 cells. J. Immunol. 2011, 187, 1778-1787. [CrossRef] [PubMed]

47. Kissick, H.T.; Sanda, M.G.; Dunn, L.K.; Pellegrini, K.L.; On, S.T.; Noel, J.K.; Arredouani, M.S. Androgens alter T-cell immunity by inhibiting T-helper 1 differentiation. Proc. Natl. Acad. Sci. USA 2014, 111, 9887-9892. [CrossRef]

48. Zhang, M.A.; Rego, D.; Moshkova, M.; Kebir, H.; Chruscinski, A.; Nguyen, H.; Akkermann, R.; Stanczyk, F.Z.; Prat, A.; Steinman, L.; et al. Peroxisome proliferator-activated receptor (PPAR)alpha and -gamma regulate IFNgamma and IL-17A production by human T cells in a sex-specific way. Proc. Natl. Acad. Sci. USA 2012, 109, 9505-9510. [CrossRef]

49. Massa, M.G.; David, C.; Jorg, S.; Berg, J.; Gisevius, B.; Hirschberg, S.; Linker, R.A.; Gold, R.; Haghikia, A. Testosterone differentially affects $\mathrm{T}$ cells and neurons in murine and human models of neuroinflammation and neurodegeneration. Am. J. Pathol. 2017, 187, 1613-1622. [CrossRef]

50. Vignozzi, L.; Cellai, I.; Santi, R.; Lombardelli, L.; Morelli, A.; Comeglio, P.; Filippi, S.; Logiodice, F.; Carini, M.; Nesi, G.; et al. Antiinflammatory effect of androgen receptor activation in human benign prostatic hyperplasia cells. J. Endocrinol. 2012, 214, 31-43. [CrossRef]

51. Trigunaite, A.; Dimo, J.; Jorgensen, T.N. Suppressive effects of androgens on the immune system. Cell Immunol. 2015, 294, 87-94. [CrossRef] [PubMed]

52. Yamatomo, T.; Okano, M.; Ono, T.; Nakayama, E.; Yoshino, T.; Satoskar, A.R.; Harn, D.A., Jr.; Nishizaki, K. Sex-related differences in the initiation of allergic rhinitis in mice. Allergy 2001, 56, 525-531. [CrossRef] [PubMed]

53. Fuseini, H.; Yung, J.A.; Cephus, J.Y.; Zhang, J.; Goleniewska, K.; Polosukhin, V.V.; Peebles, R.S., Jr.; Newcomb, D.C. Testosterone Decreases House Dust Mite-Induced Type 2 and IL-17A-Mediated Airway Inflammation. J. Immunol. 2018, 201, 1843-1854. [CrossRef] [PubMed]

54. Hepworth, M.R.; Hardman, M.J.; Grencis, R.K. The role of sex hormones in the development of Th2 immunity in a gender-biased model of Trichuris muris infection. Eur. J. Immunol. 2010, 40, 406-416. [CrossRef] [PubMed]

55. Walecki, M.; Eisel, F.; Klug, J.; Baal, N.; Paradowska-Dogan, A.; Wahle, E.; Hackstein, H.; Meinhardt, A.; Fijak, M. Androgen receptor modulates Foxp3 expression in CD4+CD25+Foxp3+ regulatory T-cells. Mol. Biol. Cell 2015, 26, 2845-2857. [CrossRef] [PubMed] 
56. Gubbels Bupp, M.R.; Jorgensen, T.N. Androgen-Induced Immunosuppression. Front. Immunol. 2018, 9, 794. [CrossRef]

57. Fuseini, H.; Newcomb, D.C. Mechanisms Driving Gender Differences in Asthma. Curr. Allergy Asthma Rep. 2017, 17, 19. [CrossRef]

58. Khurana, H.; Malhotra, P.; Sachdeva, M.U.; Varma, N.; Bose, P.; Yanamandra, U.; Varma, S.; Khadwal, A.; Lad, D.; Prakash, G. Danazol increases T regulatory cells in patients with aplastic anemia. Hematology 2018, 23, 496-500. [CrossRef]

59. Liou, C.J.; Huang, W.C. Dehydroepiandrosterone suppresses eosinophil infiltration and airway hyperresponsiveness via modulation of chemokines and Th2 cytokines in ovalbumin-sensitized mice. J. Clin. Immunol. 2011, 31, 656-665. [CrossRef]

60. Chan, C.C.; Liou, C.J.; Xu, P.Y.; Shen, J.J.; Kuo, M.L.; Len, W.B.; Chang, L.E.; Huang, W.C. Effect of dehydroepiandrosterone on atopic dermatitis-like skin lesions induced by 1-chloro-2,4-dinitrobenzene in mouse. J. Dermatol. Sci. 2013, 72, 149-157. [CrossRef]

61. Aggelakopoulou, M.; Kourepini, E.; Paschalidis, N.; Simoes, D.C.; Kalavrizioti, D.; Dimisianos, N.; Papathanasopoulos, P.; Mouzaki, A.; Panoutsakopoulou, V. ERbeta-Dependent Direct Suppression of Human and Murine Th17 Cells and Treatment of Established Central Nervous System Autoimmunity by a Neurosteroid. J. Immunol. 2016, 197, 2598-2609. [CrossRef] [PubMed]

62. Alves, V.B.; Basso, P.J.; Nardini, V.; Silva, A.; Chica, J.E.; Cardoso, C.R. Dehydroepiandrosterone (DHEA) restrains intestinal inflammation by rendering leukocytes hyporesponsive and balancing colitogenic inflammatory responses. Immunobiology 2016, 221, 934-943. [CrossRef] [PubMed]

63. Cao, J.; Yu, L.; Zhao, J.; Ma, H. Effect of dehydroepiandrosterone on the immune function of mice in vivo and in vitro. Mol. Immunol. 2019, 112, 283-290. [CrossRef] [PubMed]

64. Tabata, N.; Tagami, H.; Terui, T. Dehydroepiandrosterone may be one of the regulators of cytokine production in atopic dermatitis. Arch. Dermatol. Res. 1997, 289, 410-414. [CrossRef] [PubMed]

65. Sudo, N.; Yu, X.N.; Kubo, C. Dehydroepiandrosterone attenuates the spontaneous elevation of serum IgE level in NC/Nga mice. Immunol. Lett. 2001, 79, 177-179. [CrossRef]

66. Frantz, M.C.; Prix, N.J.; Wichmann, M.W.; van den Engel, N.K.; Hernandez-Richter, T.; Faist, E.; Chaudry, I.H.; Jauch, K.W.; Angele, M.K. Dehydroepiandrosterone restores depressed peripheral blood mononuclear cell function following major abdominal surgery via the estrogen receptors. Crit. Care Med. 2005, 33, 1779-1786. [CrossRef] [PubMed]

67. Quiroga, M.F.; Angerami, M.T.; Santucci, N.; Ameri, D.; Francos, J.L.; Wallach, J.; Sued, O.; Cahn, P.; Salomon, H.; Bottasso, O. Dynamics of adrenal steroids are related to variations in Th1 and Treg populations during Mycobacterium tuberculosis infection in HIV positive persons. PLoS ONE 2012, 7, e33061. [CrossRef]

68. Auci, D.; Kaler, L.; Subramanian, S.; Huang, Y.; Frincke, J.; Reading, C.; Offner, H. A new orally bioavailable synthetic androstene inhibits collagen-induced arthritis in the mouse: Androstene hormones as regulators of regulatory T cells. Ann. NY Acad. Sci. 2007, 1110, 630-640. [CrossRef]

69. Sulcova, J.; Hill, M.; Hampl, R.; Starka, L. Age and sex related differences in serum levels of unconjugated dehydroepiandrosterone and its sulphate in normal subjects. J. Endocrinol. 1997, 154, 57-62. [CrossRef]

70. Muller, C.R.; Migl, B.; Traupe, H.; Ropers, H.H. X-linked steroid sulfatase: Evidence for different gene-dosage in males and females. Hum. Genet. 1980, 54, 197-199. [CrossRef]

71. Carlstrom, K.; Brody, S.; Lunell, N.O.; Lagrelius, A.; Mollerstrom, G.; Pousette, A.; Rannevik, G.; Stege, R.; von Schoultz, B. Dehydroepiandrosterone sulphate and dehydroepiandrosterone in serum: Differences related to age and sex. Maturitas 1988, 10, 297-306. [CrossRef]

72. Zumoff, B.; Rosenfeld, R.S.; Strain, G.W.; Levin, J.; Fukushima, D.K. Sex differences in the twenty-four-hour mean plasma concentrations of dehydroisoandrosterone (DHA) and dehydroisoandrosterone sulfate (DHAS) and the DHA to DHAS ratio in normal adults. J. Clin. Endocrinol. Metab. 1980, 51, 330-333. [CrossRef] [PubMed]

73. Prough, R.A.; Clark, B.J.; Klinge, C.M. Novel mechanisms for DHEA action. J. Mol. Endocrinol. 2016, 56, R139-155. [CrossRef] [PubMed]

74. Zhang, J.; Qiu, X.; Gui, Y.; Xu, Y.; Li, D.; Wang, L. Dehydroepiandrosterone improves the ovarian reserve of women with diminished ovarian reserve and is a potential regulator of the immune response in the ovaries. Biosci. Trends 2015, 9, 350-359. [CrossRef] [PubMed] 
75. Qiu, X.; Gui, Y.; Xu, Y.; Li, D.; Wang, L. DHEA promotes osteoblast differentiation by regulating the expression of osteoblast-related genes and Foxp3(+) regulatory T cells. Biosci. Trends 2015, 9, 307-314. [CrossRef] [PubMed]

76. Firooz, A.; Sadr, B.; Babakoohi, S.; Sarraf-Yazdy, M.; Fanian, F.; Kazerouni-Timsar, A.; Nassiri-Kashani, M.; Naghizadeh, M.M.; Dowlati, Y. Variation of biophysical parameters of the skin with age, gender, and body region. Sci. World J. 2012, 2012, 386936. [CrossRef] [PubMed]

77. Hanley, K.; Rassner, U.; Jiang, Y.; Vansomphone, D.; Crumrine, D.; Komuves, L.; Elias, P.M.; Feingold, K.R.; Williams, M.L. Hormonal basis for the gender difference in epidermal barrier formation in the fetal rat. Acceleration by estrogen and delay by testosterone. J. Clin. Investig. 1996, 97, 2576-2584. [CrossRef]

78. Tsutsumi, M.; Denda, M. Paradoxical effects of beta-estradiol on epidermal permeability barrier homeostasis. Br. J. Dermatol. 2007, 157, 776-779. [CrossRef]

79. Harvell, J.; Hussona-Saeed, I.; Maibach, H.I. Changes in transepidermal water loss and cutaneous blood flow during the menstrual cycle. Contact Derm. 1992, 27, 294-301. [CrossRef]

80. Chen, Y.; Yokozeki, H.; Katagiri, K. Physiological and functional changes in the stratum corneum restored by oestrogen in an ovariectomized mice model of climacterium. Exp. Dermatol. 2017, 26, 394-401. [CrossRef]

81. Hung, C.F.; Chen, W.Y.; Aljuffali, I.A.; Lin, Y.K.; Shih, H.C.; Fang, J.Y. Skin aging modulates percutaneous drug absorption: The impact of ultraviolet irradiation and ovariectomy. Age (Dordr.) 2015, 37, 21. [CrossRef] [PubMed]

82. Kao, J.S.; Garg, A.; Mao-Qiang, M.; Crumrine, D.; Ghadially, R.; Feingold, K.R.; Elias, P.M. Testosterone perturbs epidermal permeability barrier homeostasis. J. Investig. Dermatol. 2001, 116, 443-451. [CrossRef] [PubMed]

83. Hanley, K.; Jiang, Y.; Holleran, W.M.; Elias, P.M.; Williams, M.L.; Feingold, K.R. Glucosylceramide metabolism is regulated during normal and hormonally stimulated epidermal barrier development in the rat. J. Lipid Res. 1997, 38, 576-584. [PubMed]

84. Komuves, L.G.; Hanley, K.; Jiang, Y.; Elias, P.M.; Williams, M.L.; Feingold, K.R. Ligands and activators of nuclear hormone receptors regulate epidermal differentiation during fetal rat skin development. J. Investig. Dermatol. 1998, 111, 429-433. [CrossRef] [PubMed]

85. Muizzuddin, N.; Marenus, K.D.; Schnittger, S.F.; Sullivan, M.; Maes, D.H. Effect of systemic hormonal cyclicity on skin. J. Cosmet. Sci. 2005, 56, 311-321. [CrossRef] [PubMed]

86. Bonamonte, D.; Foti, C.; Antelmi, A.R.; Biscozzi, A.M.; Naro, E.D.; Fanelli, M.; Loverro, G.; Angelini, G. Nickel contact allergy and menstrual cycle. Contact derm. 2005, 52, 309-313. [CrossRef]

87. Hong, S.H.; Lee, J.E.; Jeong, J.J.; Hwang, S.J.; Bae, S.N.; Choi, J.Y.; Song, H. Small proline-rich protein 2 family is a cluster of genes induced by estrogenic compounds through nuclear estrogen receptors in the mouse uterus. Reprod. Toxicol. 2010, 30, 469-476. [CrossRef]

88. Hernandez-Monge, J.; Garay, E.; Raya-Sandino, A.; Vargas-Sierra, O.; Diaz-Chavez, J.; Popoca-Cuaya, M.; Lambert, P.F.; Gonzalez-Mariscal, L.; Gariglio, P. Papillomavirus E6 oncoprotein up-regulates occludin and ZO-2 expression in ovariectomized mice epidermis. Exp. Cell Res. 2013, 319, 2588-2603. [CrossRef]

89. Zhou, Z.; Bian, C.; Luo, Z.; Guille, C.; Ogunrinde, E.; Wu, J.; Zhao, M.; Fitting, S.; Kamen, D.L.; Oates, J.C.; et al. Progesterone decreases gut permeability through upregulating occludin expression in primary human gut tissues and Caco-2 cells. Sci. Rep. 2019, 9, 8367. [CrossRef]

90. Baulieu, E.E.; Thomas, G.; Legrain, S.; Lahlou, N.; Roger, M.; Debuire, B.; Faucounau, V.; Girard, L.; Hervy, M.P.; Latour, F.; et al. Dehydroepiandrosterone (DHEA), DHEA sulfate, and aging: Contribution of the DHEAge Study to a sociobiomedical issue. Proc. Natl. Acad. Sci. USA 2000, 97, 4279-4284. [CrossRef]

91. El-Alfy, M.; Deloche, C.; Azzi, L.; Bernard, B.A.; Bernerd, F.; Coutet, J.; Chaussade, V.; Martel, C.; Leclaire, J.; Labrie, F. Skin responses to topical dehydroepiandrosterone: Implications in antiageing treatment? Br. J. Dermatol. 2010, 163, 968-976. [CrossRef] [PubMed]

92. Calvo, E.; Luu-The, V.; Morissette, J.; Martel, C.; Labrie, C.; Bernard, B.; Bernerd, F.; Deloche, C.; Chaussade, V.; Leclaire, J.; et al. Pangenomic changes induced by DHEA in the skin of postmenopausal women. J. Steroid Biochem. Mol. Biol. 2008, 112, 186-193. [CrossRef] [PubMed]

93. Papadopoulos, D.; Dietze, R.; Shihan, M.; Kirch, U.; Scheiner-Bobis, G. Dehydroepiandrosterone Sulfate Stimulates Expression of Blood-Testis-Barrier Proteins Claudin-3 and -5 and Tight Junction Formation via a Gnalpha11-Coupled Receptor in Sertoli Cells. PLoS ONE 2016, 11, e0150143. [CrossRef] [PubMed] 
94. Yosipovitch, G.; Rosen, J.D.; Hashimoto, T. Itch: From mechanism to (novel) therapeutic approaches. J. Allergy Clin. Immunol. 2018, 142, 1375-1390. [CrossRef] [PubMed]

95. Watanabe, Y.; Makino, E.; Tajiki-Nishino, R.; Koyama, A.; Tajima, H.; Ishimota, M.; Fukuyama, T. Involvement of estrogen receptor alpha in pro-pruritic and pro-inflammatory responses in a mouse model of allergic dermatitis. Toxicol. Appl. Pharmacol. 2018, 355, 226-237. [CrossRef] [PubMed]

96. Ulmann, L.; Rodeau, J.L.; Danoux, L.; Contet-Audonneau, J.L.; Pauly, G.; Schlichter, R. Dehydroepiandrosterone and neurotrophins favor axonal growth in a sensory neuron-keratinocyte coculture model. Neuroscience 2009, 159, 514-525. [CrossRef]

97. Pediaditakis, I.; Iliopoulos, I.; Theologidis, I.; Delivanoglou, N.; Margioris, A.N.; Charalampopoulos, I.; Gravanis, A. Dehydroepiandrosterone: An ancestral ligand of neurotrophin receptors. Endocrinology 2015, 156, 16-23. [CrossRef]

98. Yamaguchi, H.; Kabashima-Kubo, R.; Bito, T.; Sakabe, J.; Shimauchi, T.; Ito, T.; Hirakawa, S.; Hirasawa, N.; Ogasawara, K.; Tokura, Y. High frequencies of positive nickel/cobalt patch tests and high sweat nickel concentration in patients with intrinsic atopic dermatitis. J. Dermatol. Sci. 2013, 72, 240-245. [CrossRef]

99. Hindsen, M.; Christensen, O.B.; Moller, H. Nickel levels in serum and urine in five different groups of eczema patients following oral ingestion of nickel. Acta Derm. Venereol. 1994, 74, 176-178. [CrossRef]

100. Suarez-Farinas, M.; Dhingra, N.; Gittler, J.; Shemer, A.; Cardinale, I.; de Guzman Strong, C.; Krueger, J.G.; Guttman-Yassky, E. Intrinsic atopic dermatitis shows similar TH2 and higher TH17 immune activation compared with extrinsic atopic dermatitis. J. Allergy Clin. Immunol. 2013, 132, 361-370. [CrossRef]

101. Minang, J.T.; Troye-Blomberg, M.; Lundeberg, L.; Ahlborg, N. Nickel elicits concomitant and correlated in vitro production of Th1-, Th2-type and regulatory cytokines in subjects with contact allergy to nickel. Scand. J. Immunol. 2005, 62, 289-296. [CrossRef] [PubMed]

102. Summer, B.; Stander, S.; Thomas, P. Cytokine patterns in vitro, in particular IL-5/IL-8 ratio, to detect patients with nickel contact allergy. J. Eur. Acad. Dermatol. Venereol. 2018, 32, 1542-1548. [CrossRef] [PubMed]

103. Czarnobilska, E.; Jenner, B.; Kaszuba-Zwoinska, J.; Kapusta, M.; Obtulowicz, K.; Thor, P.; Spiewak, R. Contact allergy to nickel: Patch test score correlates with IL-5, but not with IFN-gamma nickel-specific secretion by peripheral blood lymphocytes. Ann. Agric. Environ. Med. 2009, 16, 37-41. [PubMed]

104. Ott, H.; Stanzel, S.; Ocklenburg, C.; Merk, H.F.; Baron, J.M.; Lehmann, S. Total serum IgE as a parameter to differentiate between intrinsic and extrinsic atopic dermatitis in children. Acta Derm. Venereol. 2009, 89, 257-261. [CrossRef] [PubMed]

105. Kusel, M.M.; Holt, P.G.; de Klerk, N.; Sly, P.D. Support for 2 variants of eczema. J. Allergy Clin. Immunol. 2005, 116, 1067-1072. [CrossRef] [PubMed]

106. Zafrir, Y.; Trattner, A.; Hodak, E.; Eldar, O.; Lapidoth, M.; Ben Amitai, D. Patch testing in Israeli children with suspected allergic contact dermatitis: A retrospective study and literature review. Pediatr. Dermatol. 2018, 35, 76-86. [CrossRef] [PubMed]

107. Vahter, M.; Berglund, M.; Akesson, A.; Liden, C. Metals and women's health. Environ. Res. 2002, 88, 145-155. [CrossRef] [PubMed]

108. Singh, A.K.; Cydulka, R.K.; Stahmer, S.A.; Woodruff, P.G.; Camargo, C.A., Jr. Sex differences among adults presenting to the emergency department with acute asthma. Multicenter Asthma Research Collaboration Investigators. Arch. Intern. Med. 1999, 159, 1237-1243. [CrossRef]

109. Pagtakhan, R.D.; Bjelland, J.C.; Landau, L.I.; Loughlin, G.; Kaltenborn, W.; Seeley, G.; Taussig, L.M. Sex differences in growth patterns of the airways and lung parenchyma in children. J. Appl. Physiol. Respir. Environ. Exerc. Physiol. 1984, 56, 1204-1210. [CrossRef]

110. Sears, M.R.; Burrows, B.; Flannery, E.M.; Herbison, G.P.; Holdaway, M.D. Atopy in childhood. I. Gender and allergen related risks for development of hay fever and asthma. Clin. Exp. Allergy 1993, 23, 941-948. [CrossRef]

111. Mohrenschlager, M.; Schafer, T.; Huss-Marp, J.; Eberlein-Konig, B.; Weidinger, S.; Ring, J.; Behrendt, H.; Kramer, U. The course of eczema in children aged 5-7 years and its relation to atopy: Differences between boys and girls. Br. J. Dermatol. 2006, 154, 505-513. [CrossRef] [PubMed]

112. Sennhauser, F.H.; Kuhni, C.E. Prevalence of respiratory symptoms in Swiss children: Is bronchial asthma really more prevalent in boys? Pediatr. Pulmonol. 1995, 19, 161-166. [CrossRef] [PubMed] 
113. Biro, F.M.; Huang, B.; Chandler, D.W.; Fassler, C.L.; Pinney, S.M. Impact of pubertal maturation and chronologic age on sex steroids in peripubertal girls. J. Clin. Endocrinol. Metab. 2019, 104, 2971-2977. [CrossRef] [PubMed]

114. Maruyama, Y.; Aoki, N.; Suzuki, Y.; Ohno, Y.; Imamura, M.; Saika, T.; Sinohara, H.; Yamamoto, T. Sex-steroid-binding plasma protein (SBP), testosterone, oestradiol and dehydroepiandrosterone (DHEA) in prepuberty and puberty. Acta Endocrinol. (Copenh) 1987, 114, 60-67. [CrossRef] [PubMed]

115. Rouskova, D.; Mittmann, K.; Schumacher, U.; Dietrich, H.; Zimmermann, T. Effectiveness, tolerability and acceptance of a low-dosed estradiol/dienogest formulation (Lafamme $1 \mathrm{mg} / 2 \mathrm{mg}$ ) for the treatment of menopausal complaints: A non-interventional observational study over 6 cycles of 28 days. Gynecol. Endocrinol. 2015, 31, 560-564. [CrossRef] [PubMed]

116. Yamaura, K.; Tomono, A.; Suwa, E.; Ueno, K. Sex-related differences in SLIGRL-induced pruritus in mice. Life Sci. 2014, 94, 54-57. [CrossRef] [PubMed]

117. Kitagaki, H.; Ono, N.; Hayakawa, K.; Kitazawa, T.; Watanabe, K.; Shiohara, T. Repeated elicitation of contact hypersensitivity induces a shift in cutaneous cytokine milieu from a T helper cell type 1 to a T helper cell type 2 profile. J. Immunol. 1997, 159, 2484-2491. [PubMed]

118. Raghunath, R.S.; Venables, Z.C.; Millington, G.W. The menstrual cycle and the skin. Clin. Exp. Dermatol. 2015, 40, 111-115. [CrossRef] [PubMed]

119. Kemmett, D.; Tidman, M.J. The influence of the menstrual cycle and pregnancy on atopic dermatitis. Br. J. Dermatol. 1991, 125, 59-61. [CrossRef]

120. Cho, S.; Kim, H.J.; Oh, S.H.; Park, C.O.; Jung, J.Y.; Lee, K.H. The influence of pregnancy and menstruation on the deterioration of atopic dermatitis symptoms. Ann. Dermatol. 2010, 22, 180-185. [CrossRef]

121. Ebata, T.; Itamura, R.; Aizawa, H.; Niimura, M. Serum sex hormone levels in adult patients with atopic dermatitis. J. Dermatol. 1996, 23, 603-605. [CrossRef] [PubMed]

122. Kasperska-Zajac, A.; Brzoza, Z.; Rogala, B. Dehydroepiandrosterone and dehydroepiandrosterone sulphate in atopic allergy and chronic urticaria. Inflammation 2008, 31, 141-145. [CrossRef] [PubMed]

123. Opstad, P.K. The hypothalamo-pituitary regulation of androgen secretion in young men after prolonged physical stress combined with energy and sleep deprivation. Acta Endocrinol. (Copenh) 1992, 127, 231-236. [CrossRef] [PubMed]

(C) 2019 by the authors. Licensee MDPI, Basel, Switzerland. This article is an open access article distributed under the terms and conditions of the Creative Commons Attribution (CC BY) license (http://creativecommons.org/licenses/by/4.0/). 